\title{
Satellite-Observed Multi-Scale Variability of Sea Surface Chlorophyll-a Concentration along the South Coast of the Sumatra-Java Islands
}

\author{
Tengfei Xu ${ }^{1,2,3}{ }^{1,}$, Zexun Wei ${ }^{1,2,3, *} \mathbb{C}$, Shujiang Li ${ }^{1,2,3}$, Raden Dwi Susanto ${ }^{4,5}{ }^{\circ}$, Nyoman Radiarta ${ }^{6}$, \\ Chao Yuan ${ }^{1,2,3}$, Agus Setiawan ${ }^{6}$, Anastasia Kuswardani ${ }^{6}$, Teguh Agustiadi ${ }^{6}\left(\mathbb{D}\right.$ and Mukti Trenggono ${ }^{7}$ \\ 1 Key Laboratory of Marine Science and Numerical Modeling, First Institute of Oceanography, \\ Ministry of Natural Resources, Qingdao 266061, China; xutengfei@fio.org.cn (T.X.); lisj@fio.org.cn (S.L.); \\ yuanchao@fio.org.cn (C.Y.) \\ 2 Laboratory for Regional Oceanography and Numerical Modeling, Pilot National Laboratory for Marine \\ Science and Technology, Qingdao 266237, China \\ 3 Shandong Key Laboratory of Marine Science and Numerical Modeling, Qingdao 266061, China \\ 4 Department of Atmospheric and Oceanic Science, University of Maryland, College Park, MD 20742, USA; \\ dwisusa@umd.edu \\ 5 Bandung Institute of Technology, Faculty of Earth Sciences and Technology, Bandung 40116, Indonesia \\ 6 Agency for Marine and Fisheries Research and Human Resources, Ministry of Marine Affairs and Fisheries, \\ Jakarta 14430, Indonesia; radiarta@kkp.go.id (N.R.); agus.setiawan@kkp.go.id (A.S.); \\ a.kuswardani@kkp.go.id (A.K.); teguh.agustiadi@kkp.go.id (T.A.) \\ 7 Department of Marine Science, Faculty of Fisheries and Marine Science, Jenderal Soedirman University, \\ Purwokerto 53121, Indonesia; mukti.trenggono@unsoed.ac.id \\ updates \\ * Correspondence: weizx@fio.org.cn; Tel.: +86-532-88966225
}

Citation: Xu, T.; Wei, Z.; Li, S.; Susanto, R.D.; Radiarta, N.; Yuan, C.; Setiawan, A.; Kuswardani, A.; Agustiadi, T.; Trenggono, M. Satellite-Observed Multi-Scale Variability of Sea Surface Chlorophyll-a Concentration along the South Coast of the Sumatra-Java Islands. Remote Sens. 2021, 13, 2817. https://doi.org/10.3390/rs13142817

Academic Editor: Jorge Vazquez

Received: 22 May 2021

Accepted: 8 July 2021

Published: 17 July 2021

Publisher's Note: MDPI stays neutral with regard to jurisdictional claims in published maps and institutional affiliations.

Copyright: (c) 2021 by the authors. Licensee MDPI, Basel, Switzerland. This article is an open access article distributed under the terms and conditions of the Creative Commons Attribution (CC BY) license (https:/ / creativecommons.org/licenses/by/ $4.0 /)$.

\begin{abstract}
The southern coast of Java is known as one of the most productive fishing grounds for tuna, feeding by nutrient-rich water along the coast caused by the subsurface water upwelling. This primary productivity can be evidenced by the high sea surface chlorophyll-a concentration (SSC). Based on satellite remote sensing products, we investigate the multi-scale variability in SSC along the Sumatra-Java coast. The results show that seasonal variability of SSCs is primarily due to monsoondriven upwelling and rainfall in the Indian Ocean and Indonesian seas sides of the Sumatra and Java Islands, respectively. Local Ekman pumping plays a secondary role, while rainfall input to the ocean has little effect. Coastally trapped Kelvin waves and mesoscale eddies are responsible for the intraseasonal SSC anomalies in regions along the south coast of Java and off the Sunda and Lombok Straits, respectively. The interannual variability in SSC is caused by the anomalous upwelling related to the Indian Ocean Dipole. There was a weak increasing trend of $\sim 0.1-0.2 \mathrm{mg} / \mathrm{m}^{3}$ per decade, above the global averaged trend, which may be related to enhanced local Ekman pumping. These analyses provide an overall description of SSC variations based on satellite observations; however, further investigations based on in situ observations are needed to achieve better quantification.
\end{abstract}

Keywords: chlorophyll-a; Java coastal upwelling; southeastern tropical Indian Ocean; seasonal variability; intraseasonal variability; interannual variability; trend; Kelvin waves; mesoscale eddy

\section{Introduction}

Marine primary productivity is the fundamental factor that feeds the marine ecosystems and fisheries. So far, only satellite ocean color sensors can provide coverage of global ocean chlorophyll, which in turn indicating the phytoplankton biomass and marine primary productivity [1-3]. High sea surface chlorophyll-a concentration (SSC) areas generally are identified in the upwelling and coastal areas feeding by nutrient-rich water from deeper layer and runoff, respectively (Figure 1a). The global SSC is found subject to multi-scale variability associated with ocean dynamical processes such as upwelling, mesoscale eddies, and sea ice melting [4-7]. Previous investigations show no significant trend in global 
annual median chlorophyll-a from 1998 to 2015 [8]. Among these high SSC regions, the southern coast of Java is known as one of the most productive fishing grounds for tuna as a result of the nutrient-rich water along the coast, which is caused by subsurface water upwelling (Figure 1b) [9-12]. Java coastal upwelling can be captured well by satellite images of cold sea surface temperature (SST), low sea surface height (SSH), and high SSC [13-15]. From the viewpoint of dynamics, the seasonal Java coastal upwelling is caused by winds driven offshore Ekman transport and corresponding vertical pumping [12]. In addition, the eastward propagation of upwelling Kelvin waves also generates thermocline shoaling along the Sumatra-Java coast on an intraseasonal timescale [16-19].

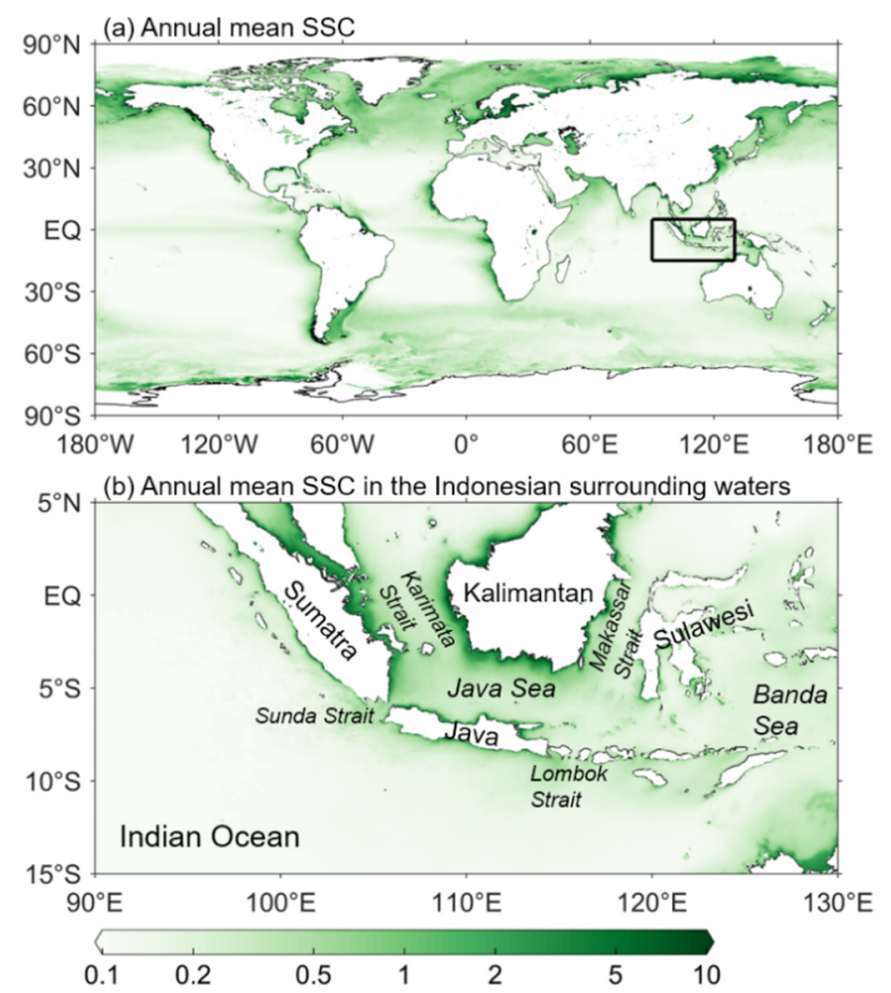

Figure 1. Distributions of annual mean SSC $\left(\mathrm{mg} / \mathrm{m}^{3}\right)$ : (a) global; (b) Indonesian surrounding waters.

During the southeast monsoon seasons, the southeasterly wind along the southern coast of Java forces offshore Ekman transport, which induces compensation upwelling off the coast [20]. The upwelling brings cold and nutrient-rich water from the subsurface to the upper layer, resulting in increased phytoplankton biomass, which is consumed by highertrophic-level organisms such as fish [21,22]. Consequently, the abundant season of fisheries production generally coincides with the monsoon-driven coastal upwelling [11,23]. Another factor responsible for the increase in SSC relies on nutrients conveyed by rainfall and river discharge during the rainy season, when the northwesterly monsoon prevails $[13,24]$. Since few rivers discharge into the Indian Ocean, there is a collective water volume flux roughly two orders smaller than that into the Indonesian seas [25]. As a result, the role of river discharge is assumed to be important only within the Indonesian seas [26], which results in fish catches peaking during the northwest monsoon seasons in the Java Sea $[27,28]$. Marine primary production can be retrieved from satellite observations of solar-induced chlorophyll fluorescence [29-31]. Thus, satellite-derived SSC has been suggested as an effective indicator for the investigation of marine productivity and the identification and assessment of fish abundance [11,32,33].

In addition to the seasonal cycle that is determined by Ekman dynamics, the SSC along the Java coast is also subject to interannual variability, which is associated with the El NiñoSouthern Oscillation (ENSO) and the Indian Ocean Dipole (IOD) events [12,33]. During El Niño and positive IOD events, there are easterly wind anomalies along the Java coast under 
a weak Walker Circulation regime, favoring generation of anomalous upwelling to enhance SSC [14,34,35], which in turn influences fish catches in the eastern Indian Ocean [10,22]. Correlation and composite analyses show that the ocean net primary production, which is closely related to the upper layer chlorophyll-a concentration, is phase lagged with ENSO by 2 months and synchronous with IOD on an interannual time scale [31]. The mechanisms by which interannual climate mode impacts the SSC surrounding the Indonesian Maritime Continent are the anomalous upwelling or downwelling in the Indian Ocean side and anomalous rainfall and river discharge in the Indonesian seas side, respectively [33]. Additionally, various types of positive IOD events drive different responses of ocean circulation, leading to different patterns in SSC anomalies in the southeastern tropical Indian Ocean [36-38].

The upwelling region along the Sumatra-Java south coast also lies on the waveguide of coastally trapped Kelvin waves. The atmospheric Madden-Julian Oscillation (MJO) forces intraseasonal equatorial Kelvin waves, which propagate eastward to arrive at the Sumatra Islands, where they are trapped as coastal Kelvin waves and propagate along the south coast of the Sumatra and Java Islands $[18,39,40]$. The propagation of upwelling Kelvin waves induces negative SSH anomalies along the Sumatra-Java south coast. When these pass the Sunda Strait, they tend to establish a sea-level gradient from the Java Sea towards the Indian Ocean along the Sunda Strait, favoring strong intraseasonal along-strait flow in the strait. The along-strait flow is the dominant mechanism accounting for the high SSC in the south mouth of the Sunda Strait at the intraseasonal time scale [41,42]. However, it is not clear if this mechanism is active in the Lombok Strait or if intraseasonal upwelling results in SSC variability on an intraseasonal time scale along the waveguide of the Kelvin waves [17,43]. A recently released satellite remote sensing product of SSC from the Copernicus Marine Service has provided high resolution data from 1998 to date. Therefore, in addition to the intraseasonal variation, we will also revisit the seasonal and interannual variation and investigate the long-term trends in the SSC along the south coast of the Sumatra and Java Islands.

This paper is organized as follows. Section 2 describes the satellite remote sensing and reanalysis products as well as the methods used. Section 3 presents the results, including: (1) the seasonal variation of SSC; (2) the intraseasonal variation of SSC and its underlying mechanism; and (3) the interannual variation and long-term trends along the south coast of the Sumatra and Java Islands. The discussion and conclusions are summarized in Sections 4 and 5.

\section{Data and Methods}

\subsection{Data}

The SSC data are the merged product, namely, OCEANCOLOUR_GLO_CHL_L4_REP_ OBSERVATIONS_009_082, which is derived by merging multi-sensors including the SeaWiFS, MODIS, MERIS, VIIRS-SNPP and JPSS1, and OLCI-S3A and S3B [44]. The metadata of the product is provided by the Copernicus Marine Service. The dataset, which is daily, with a spatial resolution of $4 \mathrm{~km}$ and available from 4 September 1997 to 30 June 2020, can be downloaded at https: / / resources.marine.copernicus.eu/?option=com_csw\&view=detail s\&product_id=OCEANCOLOUR_GLO_CHL_L4_REP_OBSERVATIONS_009_082 (accessed on 30 November 2020). The in situ measurements of chlorophyll-a at $10 \mathrm{~m}$ obtained from the World Ocean Database (WOD) 2018 are used for validation of the SSC data. The WOD2018 data can be downloaded from https: / / www.ncei.noaa.gov/products / world-ocean-database (accessed on 30 November 2020) [45]. There is rarely in situ observation of chlorophyll-a concentration in the Indian Ocean and its marginal seas. The regression between the in situ chlorophyll-a concentrations generally coincide with the satellite derived SSC, with a correlation coefficient of 0.81 , above the $99 \%$ significance level (Figure 2a). The absolute mean errors of the satellite derived SSC in the southeastern tropical Indian Ocean and the Bay of Bengal are generally smaller than $0.05 \mathrm{mg} / \mathrm{m}^{3}$ (Figure $2 \mathrm{~b}$ ). These validations suggest that the satellite derived SSC product is capable of revealing its spatial and temporal variations, albeit with uncertainty in chlorophyll-a concentration values. 


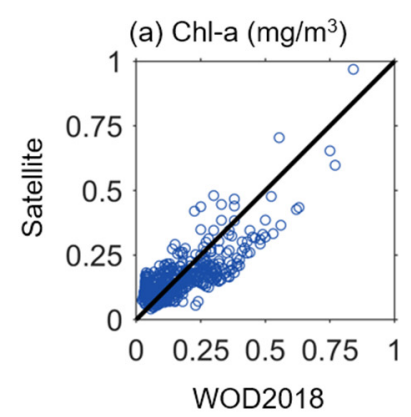

(b) Absolute mean errors $\left(\mathrm{mg} / \mathrm{m}^{3}\right)$

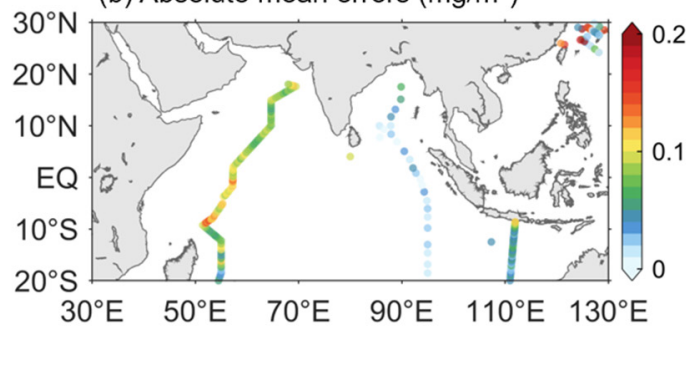

Figure 2. (a) Regression between WOD2018 in situ observed (x-axis) and satellite derived (y-axis) chlorophyll-a concentration. (b) Absolute mean errors between satellite derived SSC and in situ observed $10 \mathrm{~m}$ chlorophyll-a concentration in the Indian Ocean.

The SST data are obtained from the Group for High Resolution Sea Surface Temperature (GHRSST), which are compiled on a $0.05^{\circ} \times 0.05^{\circ}$ grid covering the period of April 2006 to date [46,47]. The SSH and sea surface geostrophic currents data are from Version 5.0 of the daily gridded absolute dynamic topography products. The products are produced by the Segment Sol multi-missions dALTimetrie, d'orbitographie et de localisation précise/Data Unification and Altimeter Combination System (SSALTO/DUACS), and distributed by the Archiving, Validation, and Interpretation of Satellite Oceanographic (AVISO). The data can be downloaded from http:/ / www.aviso.altimetry.fr/duacs/ (accessed on 30 November 2020). The dataset is daily, with a resolution of $0.25^{\circ} \times 0.25^{\circ}$ and available from October 1992 to date [48]. The sea surface wind (SSW) data are the 10-m wind fields from the Cross Calibrated Multi-Platform (CCMP) Version 2.0 with a horizontal resolution of $0.25^{\circ} \times 0.25^{\circ}$ and time interval of $6 \mathrm{~h}$, provided by the National Aeronautics and Space Administration (NASA) since 2009 [49]. The rainfall data are the daily product of the research quality three-hourly TRMM Multi-Satellite Precipitation Analysis (version 3B42), with a horizontal resolution of $0.25^{\circ} \times 0.25^{\circ}$ and can be downloaded at https:/ / disc.gsfc.nasa.gov/datasets/TRMM_3B42_Daily_7/summary (accessed on 30 November 2020) [50]. The river discharge is obtained from the GloFAS-ERA5 operational global river discharge re-analysis product. The data are a global gridded dataset with a horizontal resolution of $0.1^{\circ} \times 0.1^{\circ}$ and a daily step, with a period covering 1 January 1979 to near real-time [51]. In this study, all of the data used are during the same period of 1 January 1998 to 31 December 2019.

\subsection{Methods}

Ekman pumping is calculated as follows:

$$
w_{E}=-\nabla \times\left(\frac{\tau}{\rho f}\right)
$$

where $\tau$ is the wind stress calculated from the 10-m wind of CCMP Version 2.0, $\rho$ is the mean sea water density, which was taken to be $1.025 \times 10^{3} \mathrm{~kg} / \mathrm{m}^{3}$, and $f$ is the Coriolis parameter. The intraseasonal anomalies is obtained by the application of a 20-90-days bandpass filter to the raw time series. The positive intraseasonal SSC event is defined as positive peaks, one standard deviation above the mean value of the area averaged intraseasonal SSC. The averaged areas are marked as the Java south coast (Region A), south of the Sunda Strait (Region B), and south of the Lombok Strait (Region C). The composite analyses are then achieved by averaging the identified positive intraseasonal SSC events in regions $\mathrm{A}, \mathrm{B}$, and $\mathrm{C}$, respectively.

The Empirical Orthogonal Function (EOF) analysis is conducted using the Climate Data Toolbox for MATLAB developed by Greeneet al. [52]. EOF method is commonly used for time series analysis to reveal possible spatial patterns of climate variability and how they change with time [53]. The EOF method has been employed to explain SSC variability 
in the Indo-Pacific Oceans, Southern Oceans, and Arabian Sea [31,54,55]. To avoid the large gradient of SSC raw values in the study area, the logarithm of monthly mean SSC values was used for anomaly calculation and ensuing EOF analysis.

The Oceanic Niño Index (ONI) is provided by the National Oceanic and Atmospheric Administration (NOAA) (https://ggweather.com/enso/oni.html (accessed on 30 November 2020). The Dipole Mode Index (DMI) for the Indian Ocean Dipole (IOD) is defined as the differences in area averaged SST anomalies between the western $\left(10^{\circ} \mathrm{S}-10^{\circ} \mathrm{N}, 50^{\circ} \mathrm{E}-70^{\circ} \mathrm{E}\right)$ and southeastern $\left(10^{\circ} \mathrm{S}-0^{\circ}, 90^{\circ} \mathrm{E}-110^{\circ} \mathrm{E}\right)$ tropical Indian Ocean [56].

\section{Results}

\subsection{Seasonal Variability: Roles of Monsoon}

Seasonally, the SSC distributions are dominated by monsoon-driven upwelling along the southern coast of Java and monsoon-induced rainfall/river discharge within the Indonesian seas, respectively (Figure 3). As a result, the SSCs are lower and higher in the Indian Ocean side of the Sumatra and Java Islands during the northwesterly and southeasterly monsoon seasons, respectively (Figure $3 a, b$ ). This is attributed to monsoon-driven downwelling and upwelling as evidenced by warmer and colder SST, respectively (Figure 3c,d). Conversely, the SSCs on the Indonesian seas side, are higher and lower during the northwesterly and southeasterly monsoon seasons, respectively, which are attributed to rainy and dry weather and the associated volumes of river discharge (Figure 3e-h). Specifically, the high Chla values are confined to coastal regions surrounding the south of Kalimantan in boreal winter (Figure 3a). This is because westerly winds force onshore Ekman transport, preventing the high Chla waters along the coast from being transported southward (Figure 3c). Comparatively, the high Chla extends eastward in the east of Sumatra in response to offshore Ekman transport during winter. The Chla levels in the open areas of the Java Sea are higher in summer than in winter, which is also explained by the fact that offshore Ekman transport favors southward transport of high Chla waters from the south coast of Kalimantan (Figure 3b,d). The rainfall distributions indicate that it is rainy in the southeastern tropical Indian Ocean and Java Sea during winter (Figure 3e,f). However, the Chla levels are low in the southeastern tropical Indian Ocean and southern Java Sea, suggesting that rainfall input contributes little to Chla increase. In comparison, river discharges from the Sumatra and Kalimantan Islands are the dominant contributors to the high Chla levels surrounding the two Islands in winter (Figure $1 \mathrm{~g}, \mathrm{~h}$ ).

Figure 4 shows the area averaged Chla in response to monsoon-driven processes. The Chla in the Indian Ocean side is less than $0.4 \mathrm{mg} / \mathrm{m}^{3}$ during the non-upwelling season (December to the following May) and increases to around $1.0 \mathrm{mg} / \mathrm{m}^{3}$ during the upwelling season (June-November) (Figure 4a). The zonal winds basically show consistent seasonal cycles in both the Indian Ocean and Indonesian seas sides. On the contrary, the wind stress forces out-of-phase seasonal cycles, which are positive and negative in the Indian Ocean and Indonesian seas sides during the southeasterly monsoon season, respectively (Figure $4 b, c$ ). The rainfall over the entire maritime continent is dry during the upwelling season, whereas it is wet during the non-upwelling season. As a result, there are larger river discharges into the Indonesian seas during the non-upwelling season (Figure 4e,f). Note that only a few rivers empty into the Indian Ocean; therefore, river input does not induce high Chla levels in the Indian Ocean side in winter.

\subsection{Intraseasonal Variability}

\subsubsection{Role of Atmospheric and Oceanic Intraseasonal Oscillations}

Figure 5a shows the pattern of standard deviation of the intraseasonal SSC surrounding the Indonesian archipelago. Large intraseasonal variations occur along the southeast coast of the Sumatra and Java Islands. In addition, in the region off the Sunda and Lombok straits in the Indian Ocean (regions A and B in Figure 5a), there are also strong intraseasonal signals with variation values up to $\sim 2 \mathrm{mg} / \mathrm{m}^{3}$. The intraseasonal Ekman pumping and SSH show larger variations along the southeast coast of the Sumatra and Java Islands, 
implying close relationships between the along-shore local winds, upwelling, and SSC on an intraseasonal time scale (Figure $5 b, c)$. The intraseasonal variability of rainfall is zonally distributed with eastward attenuation, which is in accordance with the propagation of atmospheric MJO [57,58].

(a) SSC in Feb $\left(\mathrm{mg} / \mathrm{m}^{3}\right)$

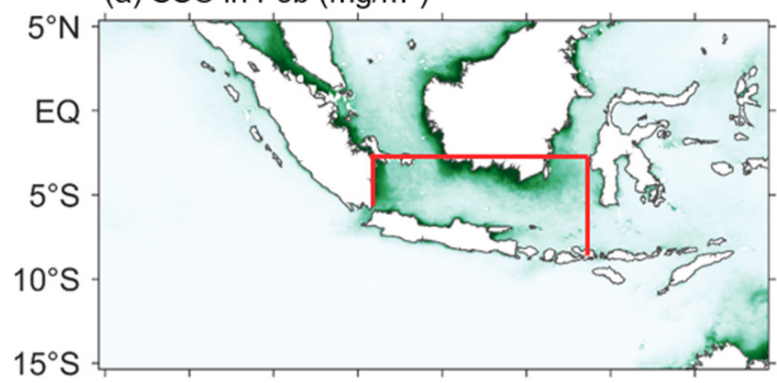

(c) Wind stress and SST in Feb $\left({ }^{\circ} \mathrm{C}\right)$

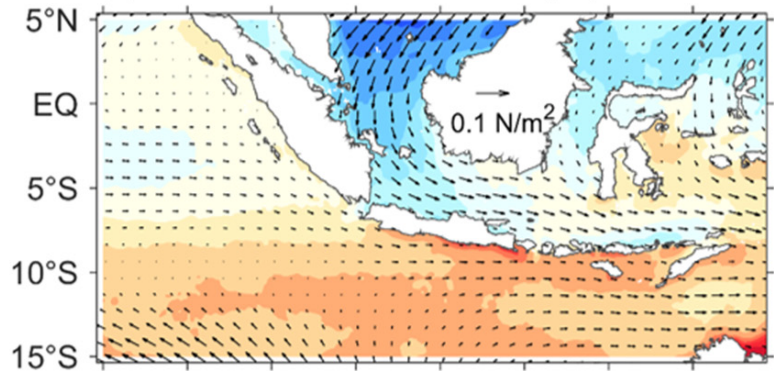

(e) Rainfall in Feb (mm/day)

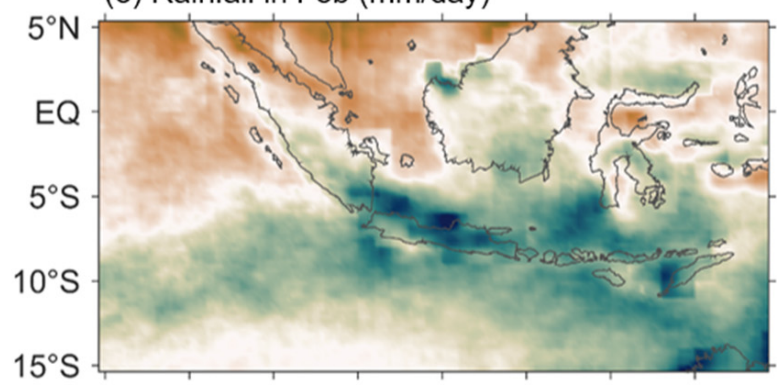

(g) River discharge in Feb $\left(10^{3} \mathrm{~m}^{3} / \mathrm{s}\right)$

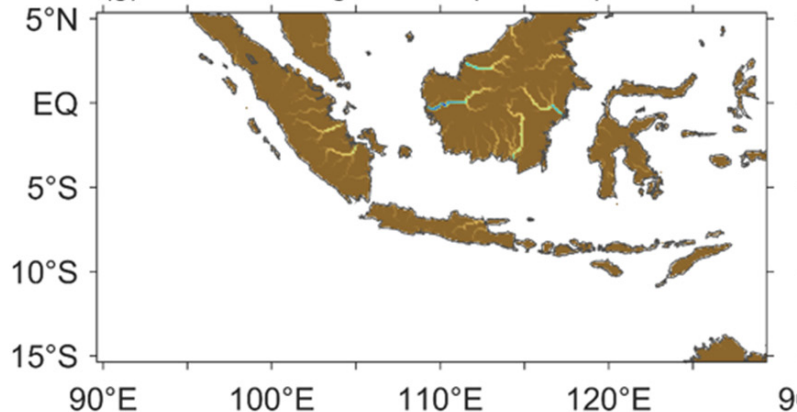

(b) SSC in Aug $\left(\mathrm{mg} / \mathrm{m}^{3}\right)$

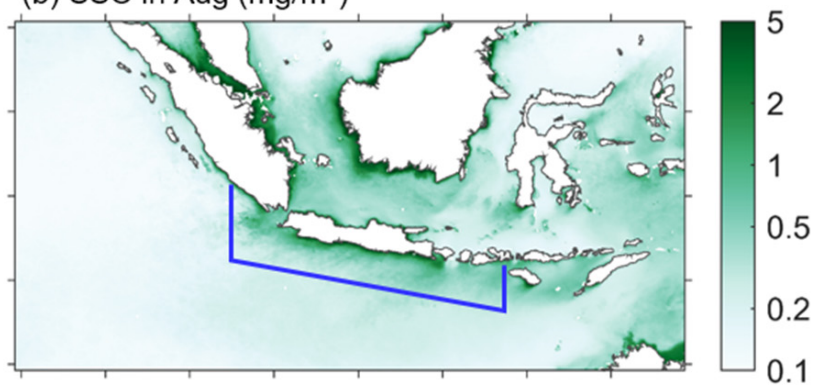

(d) Wind stress and SST in Aug $\left({ }^{\circ} \mathrm{C}\right)$

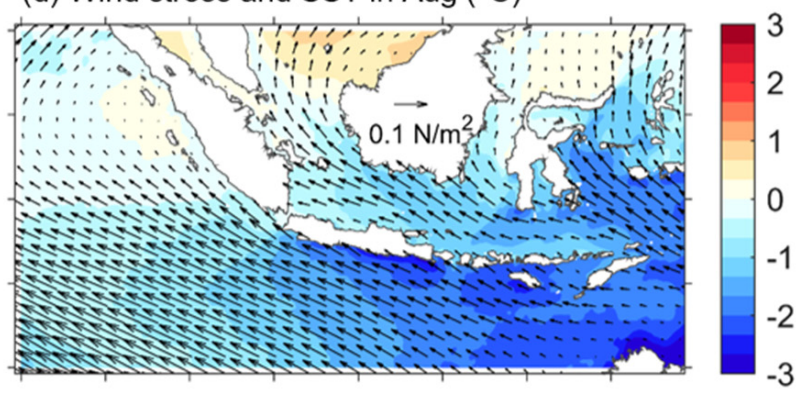

(f) Rainfall in Aug (mm/day)

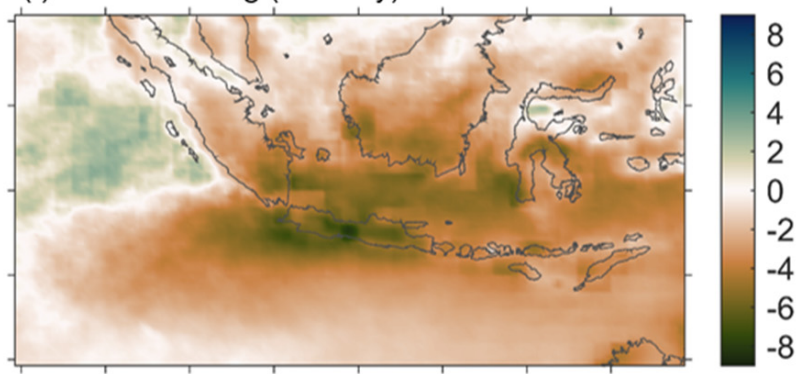

(h) River discharge in Aug $\left(10^{3} \mathrm{~m}^{3} / \mathrm{s}\right)$

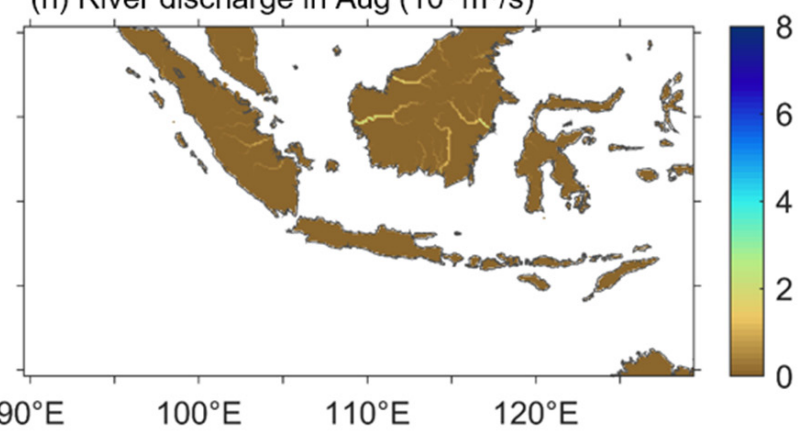

Figure 3. SSC distribution in the southeastern tropical Indian Ocean and Indonesian seas associated with monsoon-driven processes: SSC in (a) February and (b) August; wind stress (vectors) and SST (shaded) in (c) February and (d) August; rainfall in (e) February and (f) August; river discharge in (g) February and (h) August. The areas enclosed by red and blue lines in Figure $1 \mathrm{a}, \mathrm{b}$ are defined as the Indonesian seas side and Indian Ocean side, respectively. The variables are Monthly mean climatological values during the period of 1998 to 2019. 


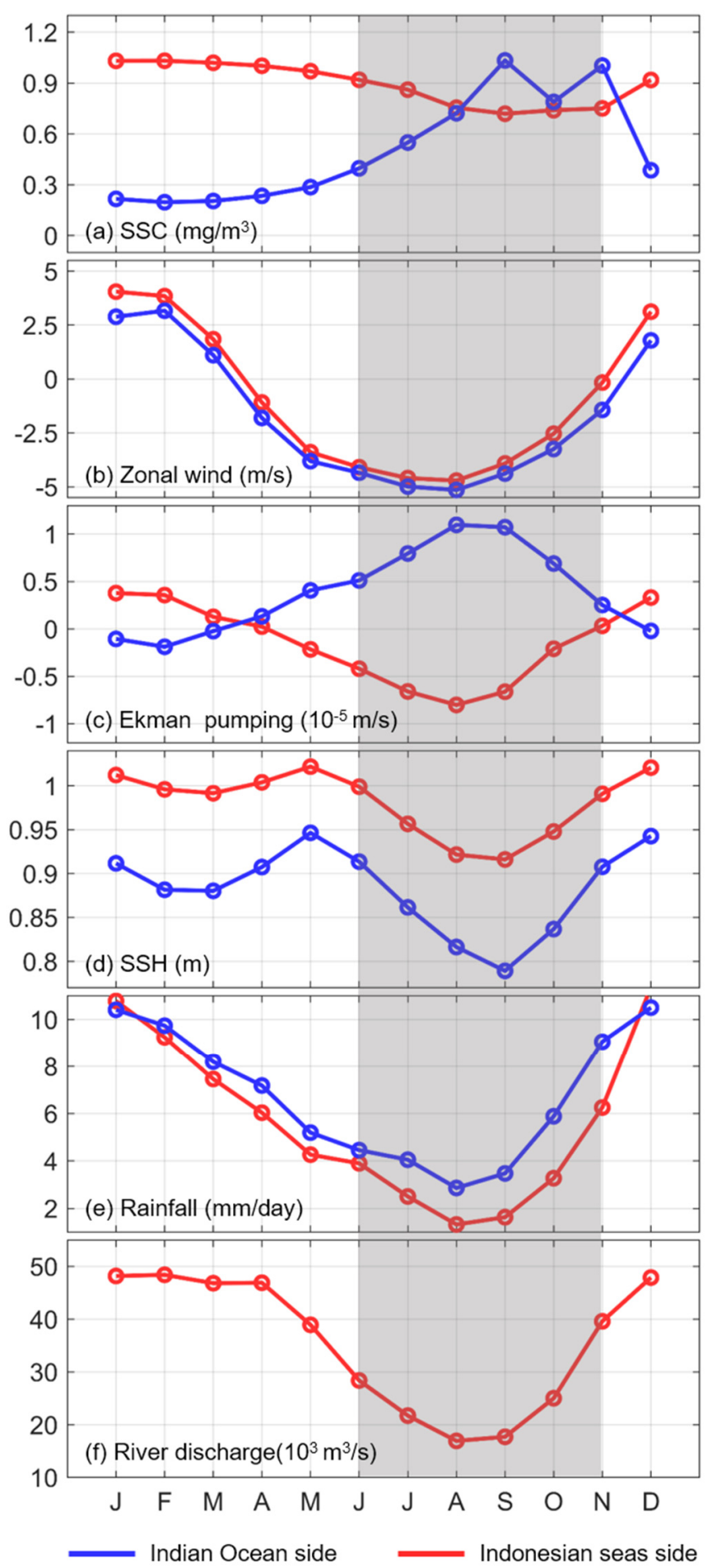

Figure 4. Climatological monthly mean variables during the period of 1998 to 2019. averaged over the areas of the Indian Ocean (area enclosed by blue lines area in Figure 1b) and Indonesian seas (area enclosed by red lines in Figure 1a) sides: (a) SSC; (b) sea surface zonal wind; (c) Ekman pumping; (d) SSH; (e) rainfall; (f) river discharge into the Indonesian seas. Note that only few small rivers empty into the Indian Ocean; therefore, they can be ignored. The gray-shaded area indicates the upwelling season. 
(a) SSC $\left(\mathrm{mg} / \mathrm{m}^{3}\right)$

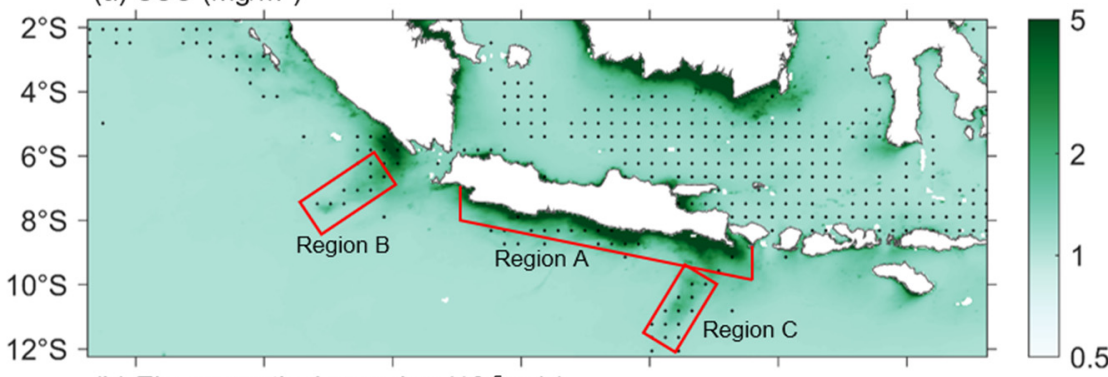

(b) Ekman vertical pumping $\left(10^{-5} \mathrm{~m} / \mathrm{s}\right)$

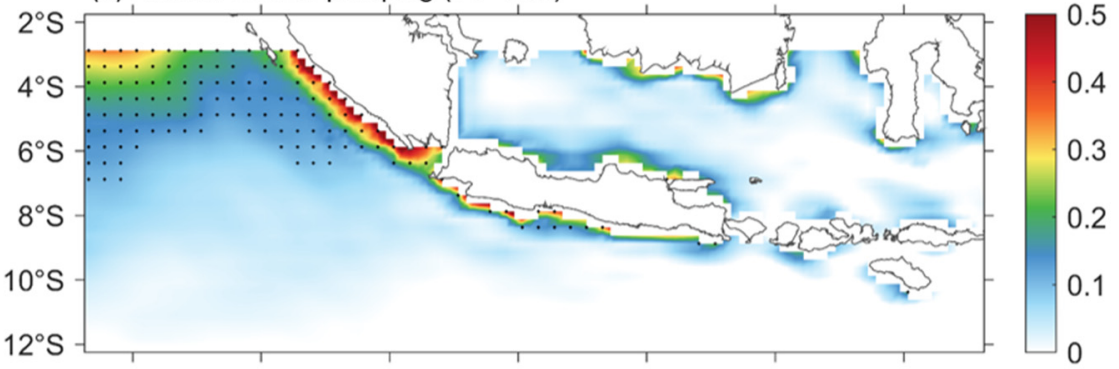

(c) SSH (m)
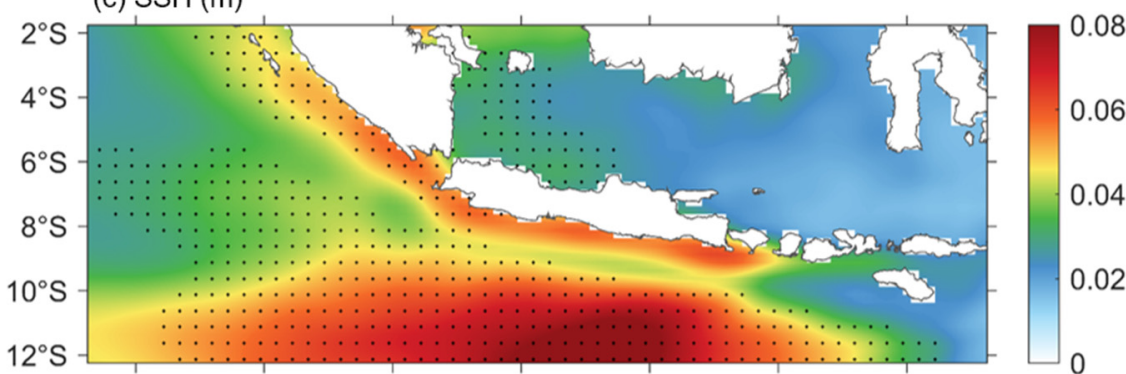

(d) Rainfall (mm/day)

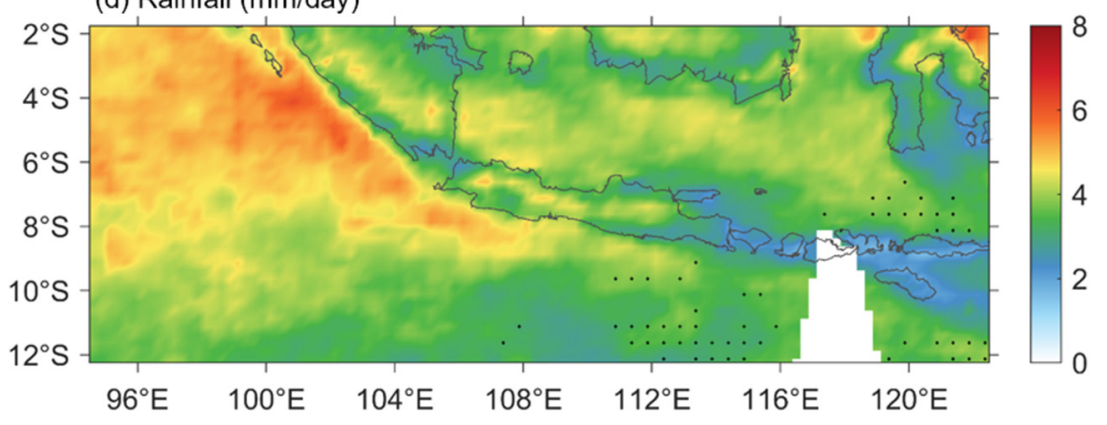

Figure 5. Distributions of the standard deviation of the intraseasonal time series during the period of 1 January 1998 to 31 December 2019: (a) SSC, with intraseasonal variation accounting for more than $50 \%$ of the total variation marked by crosses; (b) the same as (a) but for Ekman vertical pumping and intraseasonal variation accounting for $10 \%$; (c) the same as (a) but for SSH and intraseasonal variation accounting for 50\%; (d) the same as (a) but for rainfall and intraseasonal variation accounting for $50 \%$. The intraseasonal time series are extracted from raw data by employing a 20-90-days bandpass filter.

Figure 6 shows the lag correlations of the area averaged SSC along the Sumatra-Java southern coast with the SSH, Ekman pumping, and rainfall over the Indian Ocean and Indonesian seas that surround the Sumatra and Java Islands. There are significant nega tive correlations in the equatorial Indian Ocean with the SSC when they lagged the SSH by 20 days (Figure 6a). The significant negative correlations move eastward to reach the west coast of Sumatra and then move southeastward along the Sumatra-Java southern coast in the following days (Figure 6b,c). The eastward and along-coast movements of these significant correlations are caused by the propagation of intraseasonal Kelvin waves. An intraseasonal upwelling signal generated in the central equatorial Indian Ocean takes about 20 days to arrive at the Lombok Strait or even further east, thereby inducing vertically 
upward transport of nutrient-rich water and favoring positive SSC anomalies along the waveguide. The phase speed can be roughly estimated to be $1.72-2.31 \mathrm{~m} / \mathrm{s}$, which is in agreement with the first and second baroclinic modes of Kelvin waves [16,40,59]. In contrast, there are no significant correlations of the SSC with Ekman pumping and rainfall along the Sumatra-Java coasts, suggesting little contribution of the two processes at the intraseasonal time scale (Figure $6 \mathrm{~d}-\mathrm{i}$ ). The significant negative and positive correlations in the equatorial Indian Ocean in Figure 6g, $i$ are because of that the MJO related rainfall is significantly correlated with the propagation of MJO forced Kelvin waves. Notably, the correlations in Figure 6a-c show eddy-like trains along the zonal band between $10^{\circ}$ and $15^{\circ} \mathrm{S}$, implying eddy-induced SSC in this region.

(a) Lag SSH 20 days

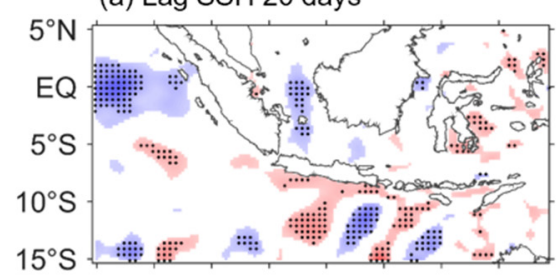

(b) Lag SSH 10 days

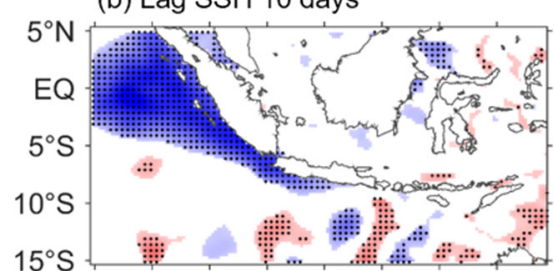

(c) Lag SSH 0 days

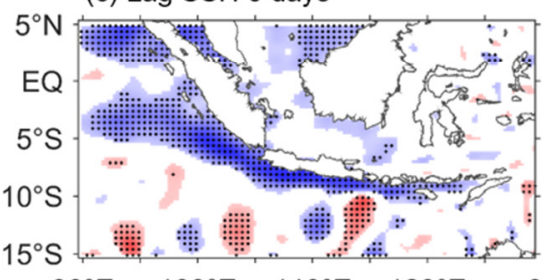

$90^{\circ} \mathrm{E} \quad 100^{\circ} \mathrm{E} \quad 110^{\circ} \mathrm{E} \quad 120^{\circ} \mathrm{E} \quad 90^{\circ} \mathrm{E}$ (d) Lag Ekman pumping 20 days

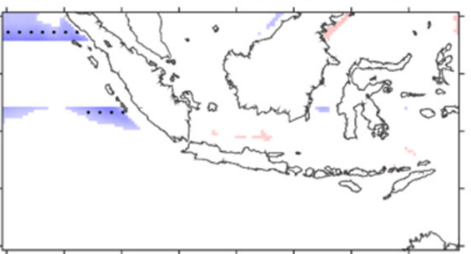

(e) Lag Ekman pumping 10 days

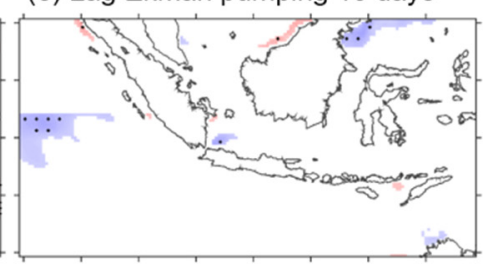

(f) Lag Ekman pumping 0 days (g) Lag Rainfall 20 days

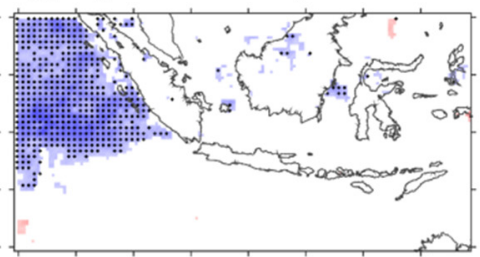

(h) Lag Rainfall 10 days

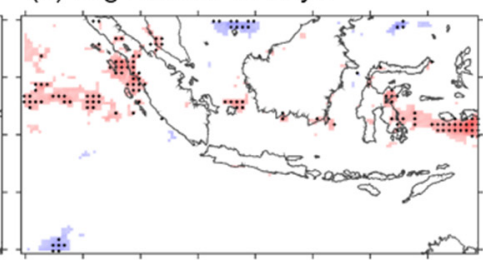

(i) Lag Rainfall 0 days

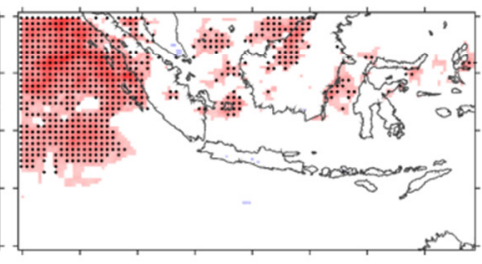

$\begin{array}{lllllllllllll}-0.3 & -0.25 & -0.2 & -0.15 & -0.1 & -0.05 & 0 & 0.05 & 0.1 & 0.15 & 0.2 & 0.25 & 0.3\end{array}$

Figure 6. Correlations between the area averaged (Region A) intraseasonal SSC and the intraseasonal SSH with (a) 20 days lag; (b) 10 days lag; (c) 0 days lag; (d-f) same as (a-c) but correlated to Ekman pumping; (g-i) same as (a-c) but correlated to rainfall. The intraseasonal time series are extracted from raw data during the period of 1 January 1998 to 31 December 2019 by employing a 20-90-days bandpass filter.

Figure 7 shows the composite analyses of the intraseasonal events identified as positive peaks, one standard deviation above the long-term mean of the 20-90-days bandpassfiltered SSC averaged in the Java southern coast (Region A in Figure 7a). The intraseasonal SSC events are generally out of phase with the SSH, with intraseasonal SSH leading by 2-3 days (Figure $7 \mathrm{~b}$ ). The typical period of the intraseasonal SSC events is approximately 28 days, which is consistent with that of the SSH. Figure 7c shows the Hovmöller plot of the composite intraseasonal SSH along the south coast of the Sumatra-Java Islands. Eastward propagation of intraseasonal Kelvin waves along the Sumatra-Java south coast is clearly revealed in the figure. The phase speed can be roughly estimated as $1.87 \pm 0.25 \mathrm{~m} / \mathrm{s}$, in agreement with the first two baroclinic modes of Kelvin waves. The Hovmöller plot of the intraseasonal SSC is similar to that of SSH with several days phase lag, suggesting that the positive SSC along the coast at an intraseasonal time scale is induced by the propagation of upwelling Kelvin waves (Figure 7d). 
(a) Pathway of Kelvin waves

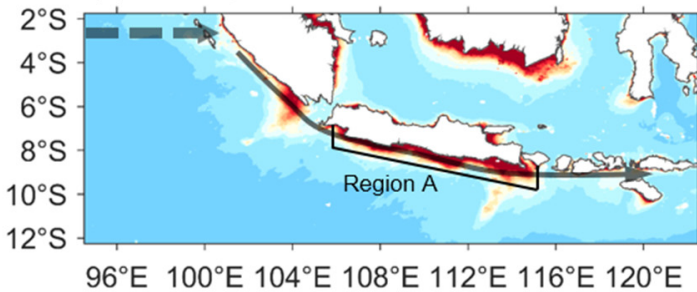

(c) Hovmöller plot of intraseasonal SSH (m)

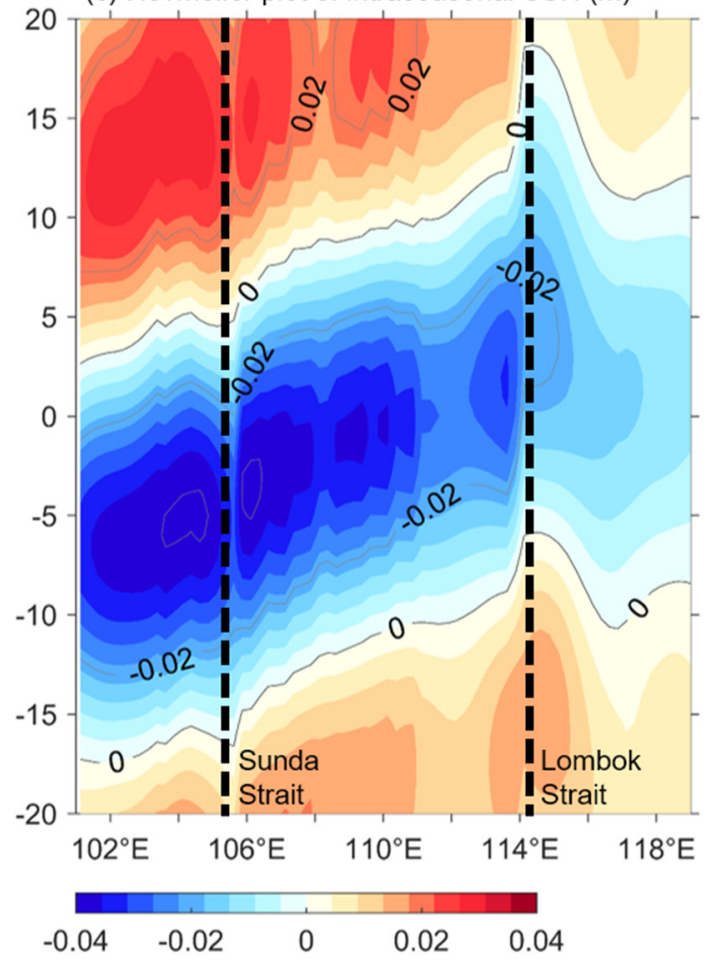

(b) Composite intraseasonal SSH (m) \& SSC $\left(\mathrm{mg} / \mathrm{m}^{3}\right)$

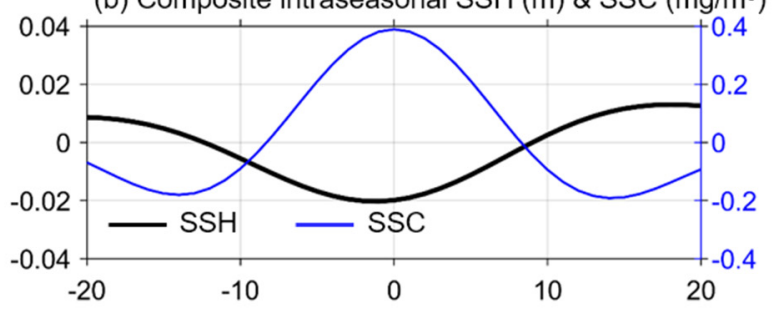

(d) Hovmöller plot of intraseasonal SSC $\left(\mathrm{mg} / \mathrm{m}^{3}\right)$

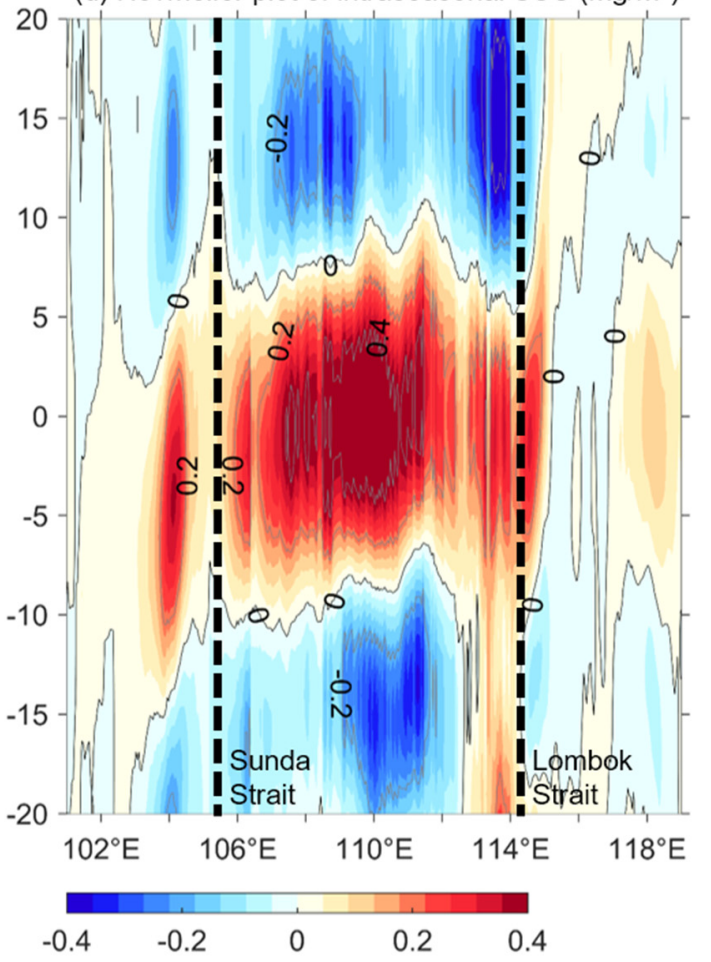

Figure 7. (a) Standard deviation of the intraseasonal SSC and the pathway of the Kelvin waves; (b) composite intraseasonal SSC and corresponding SSH in the southern coast of Java (Region A); (c) Hovmöller plot of the composite intraseasonal SSH along the southeastern coast of the Sumatra and Java Islands; (d) same as (c) but for intraseasonal seas surface Chla; Day 0 in $(\mathbf{b}-\mathbf{d})$ refers to the peak of the positive SSC intraseasonal events. The dark dashed lines in (c,d) indicate the locations of the Sunda and Lombok Straits. The intraseasonal time series are extracted from raw data during the period of 1 January 1998 to 31 December 2019 by employing a 20-90-days bandpass filter.

\subsubsection{Role of Mesoscale Eddies}

Figure 8 shows the correlations between the area averaged intraseasonal SSC south of the Sunda Strait (Region B in Figure 5) or of the Lombok Strait (Region C in Figure 5) and the intraseasonal SSH in the southeastern tropical Indian Ocean and Indonesian seas. Neither regions show significant correlations along the pathway of the Kelvin waves, suggesting that Kelvin-wave-induced upwelling is not the dominant force influencing intraseasonal SSC south of the Sunda and Lombok Straits. Instead, there are zonally distributed eddy-like significant positive-negative correlations in the southeastern tropical Indian Ocean, implying that the active mesoscale eddies may play important roles in the intraseasonal SSC south of the Sunda and Lombok Straits, as suggested by Yang et al. [60]. 
(a) Correlation between SSC in region B and SSH

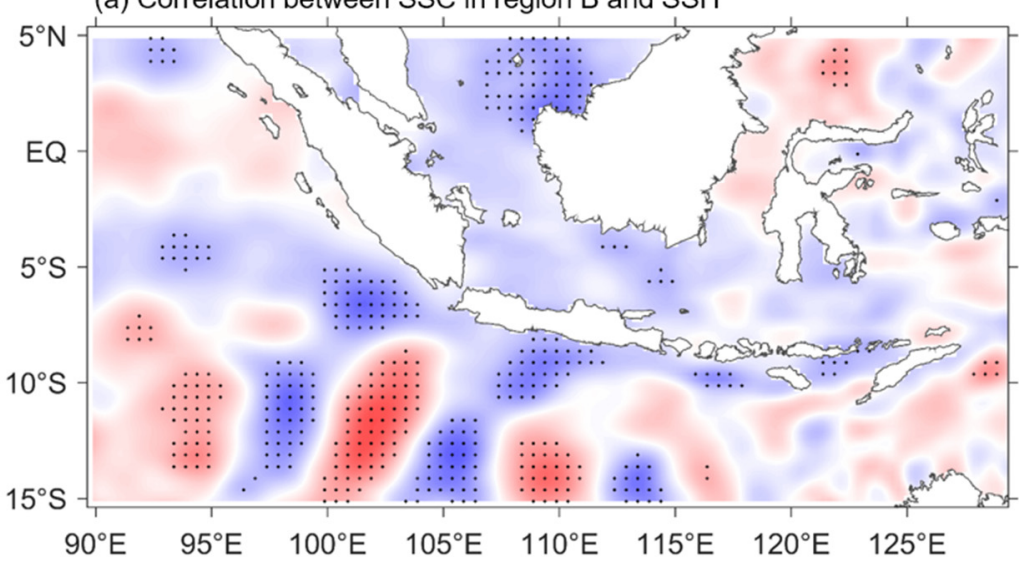

(b) Correlation between SSC in region $\mathrm{C}$ and $\mathrm{SSH}$

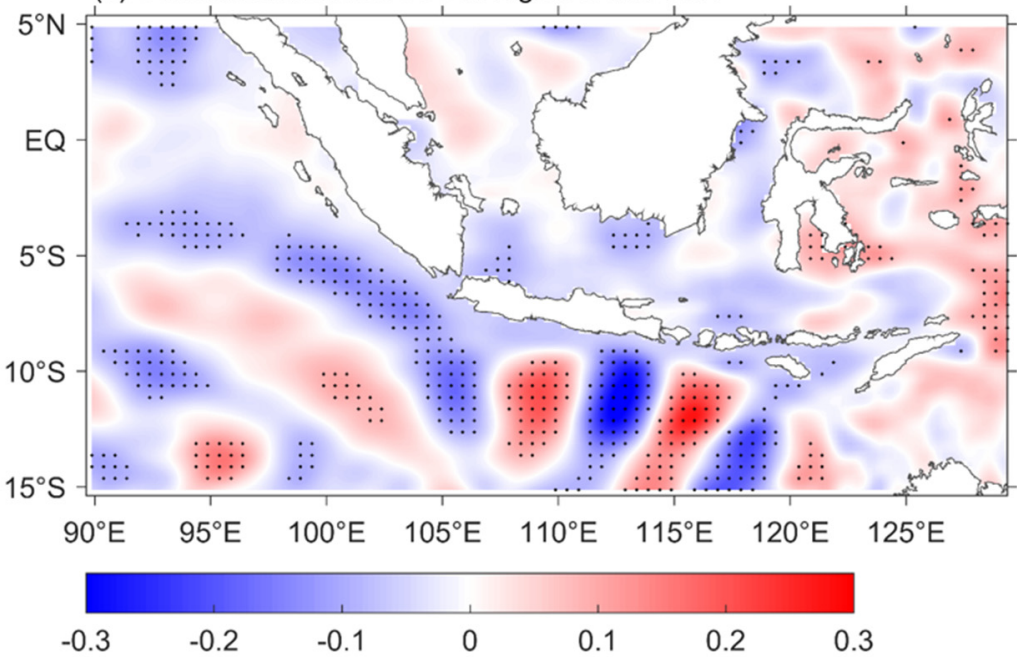

Figure 8. (a) Correlations between the area averaged intraseasonal SSC south of the Sunda Strait (Region B in Figure 3a) and intraseasonal SSH; (b) same as (a) but for the area averaged intraseasonal SSC south of Lombok Strait (Region C in Figure 3a). The intraseasonal time series are extracted from raw data during the period of 1 January 1998 to 31 December 2019 by employing a 20-90-days bandpass filter.

The composite intraseasonal SSC events in the south of Sunda Strait (Region B) suggest a statistically mean period of 28-29 days, which coincides with the period of Kelvin-waveinduced intraseasonal SSC along the south coast of Java (Figure 9a). There is also in-phase variability of intraseasonal SSC along the south coast of Java (Region A) with that in Region B. Of this intraseasonal SSC in Region A, its peak value $\left(0.26 \pm 0.25 \mathrm{mg} / \mathrm{m}^{3}\right)$ is approximately twice that in Region B $\left(0.13 \pm 0.24 \mathrm{mg} / \mathrm{m}^{3}\right)$ (Figure 9a) but is half that induced by Kelvin wave propagation (Figure 7b). The intraseasonal SSC in the south of Lombok Strait (Region C) does not show phase relationships with the SSC in regions A and $B$, and its peak is approximately $0.06 \pm 0.27 \mathrm{mg} / \mathrm{m}^{3}$, which is roughly half of that in Region B (Figure 9a). The SSC distribution at the positive peak of intraseasonal SSC events in Region B is shown in Figure 9b. In addition to the high SSC in the south of Sunda Strait, which was expected, high SSC is also found along the south coast of Java, suggesting that the intraseasonal SSC in Region B partly co-occurred with that in Region C. As shown in Figure 9c, there is a cyclonic mesoscale eddy located near the southwest of Sumatra, and this is accompanied by negative SSH anomalies along the Java coast at the peak of intraseasonal SSC events in Region B, in accordance with the distribution of SSC. Similar analyses have been conducted for Region C, which is located south of the Lombok Strait (Figure 9d-f). The period of intraseasonal SSC events in Region C is around 33 days, with a peak value of approximately $0.17 \pm 0.38 \mathrm{mg} / \mathrm{m}^{3}$. The intraseasonal SSC in Region $\mathrm{C}$ leads that in Region A by about 2 days, suggesting it is not induced by the eastward 
propagation of upwelling Kelvin waves since Region A is upstream of the waveguide (Figure 9d). At the peak of the positive intraseasonal SSC in Region C, while the SSC is high, a series of alternate arrangements of anticyclonic and cyclonic eddies are observed in the southeastern tropical Indian Ocean, with a cyclonic eddy coinciding with the high SSC center (Figure 9e,f). The alternate arrangement of anticyclonic and cyclonic eddies explains the distribution of significant positive and negative correlations in Figure 8b.

(a) Composite SSC corresponds to Region B

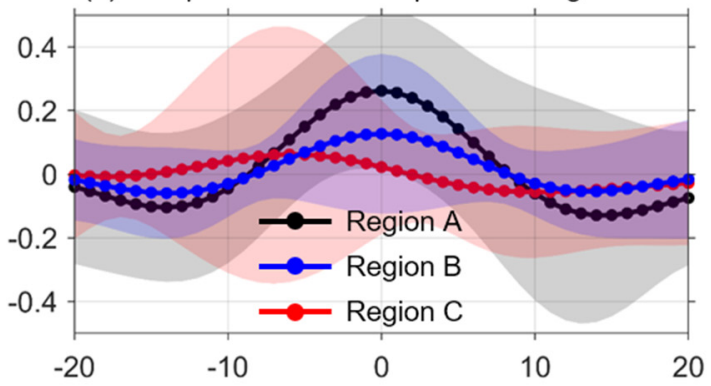

(b) Composite SSC corresponds to Region B

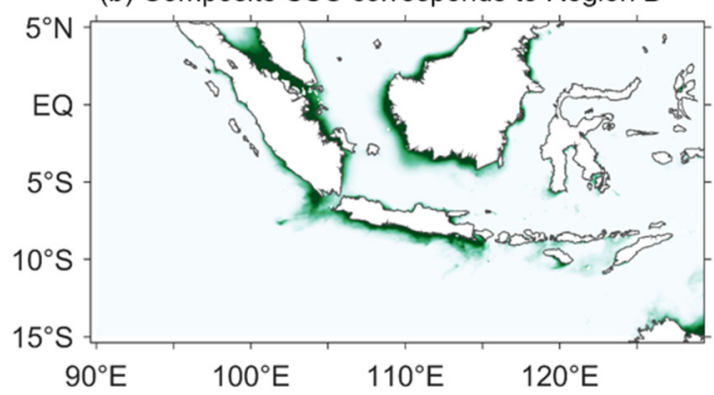

(c) Composite SSH corresponds to Region B

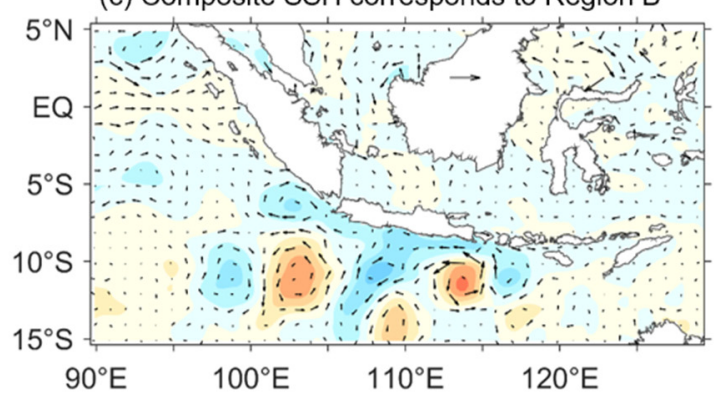

(d) Composite SSC corresponds to Region C

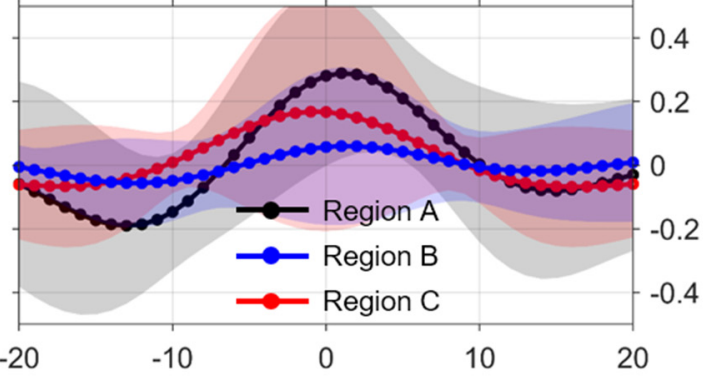

(e) Composite SSC corresponds to Region C

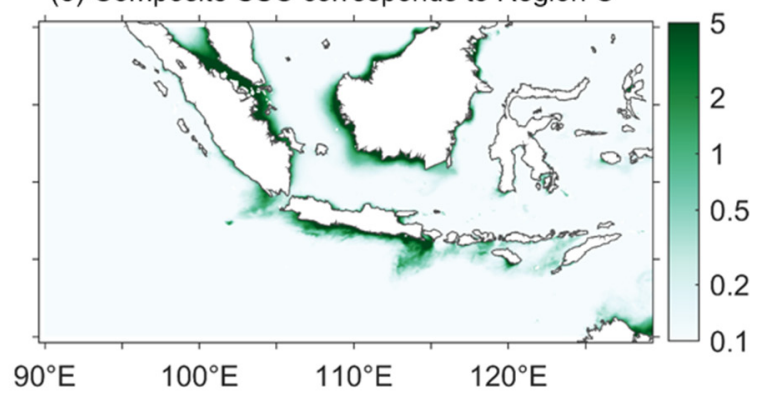

(f) Composite SSH corresponds to Region C

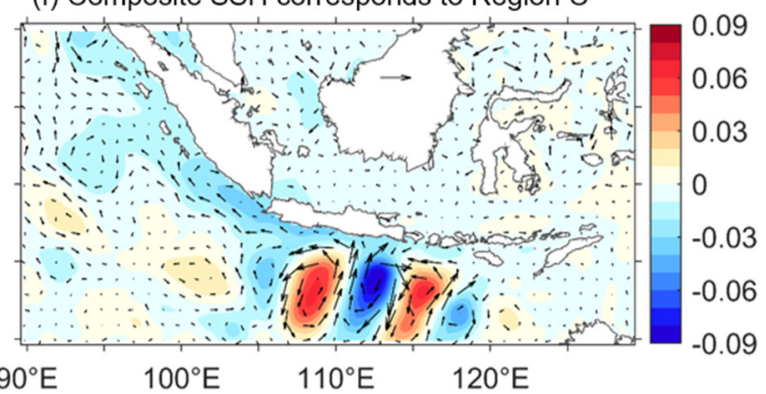

Figure 9. (a) Composite intraseasonal SSC averaged south of the Sunda Strait (Region B), and corresponding intraseasonal SSC averaged along the south coast of Java Island (Region B) and south of the Lombok Straits (Region C); (b) composite SSC distribution at the peak of the positive phases of intraseasonal SSC in Region B; (c) same as (b) but for intraseasonal SSH (shaded) and sea surface geostrophic currents (vector); (d-f) same as (a-c) but for the intraseasonal SSC averaged south of Lombok Strait (Region C). The intraseasonal time series are extracted from raw data during the period of 1 January 1998 to 31 December 2019 by employing a 20-90-days bandpass filter. Light shadings in (a,d) indicate the standard deviation of the composite intraseasonal SSC in regions A (gray), B (blue), and C (red).

\subsection{Interannual Variability and Long-Term Trends}

EOF analysis was used to reveal the interannual variability of SSC along the south coast of the Sumatra and Java Islands. To avoid the large gradient of SSC raw values in the study area, the logarithm of monthly mean SSC values was used for anomaly calculation and ensuing EOF analysis. The first three leading modes account for $70.56 \%, 15.01 \%$, and $14.42 \%$ of the total variance, respectively. The first EOF mode shows a pattern reminiscent of that of the eastern pole of the IOD (Figure 10a). Indeed, the time coefficient of the first EOF mode (PC1) coincided with the area averaged monthly SSC anomalies along the south coast of the Sumatra and Java Islands and the DMI indices (Figure 10b). Lag 
correlations show that the PC1 is synchronously correlated with DMI, between which the correlation coefficient is 0.78 (Figure 10c). In comparison, the lag correlations between PC1 and ONI show negative correlations above the $95 \%$ significance level with PC1 lagging by 6-11 months (Figure 10d). The lag correlations of PC1 with ONI are a consequence of the relationship between DMI and ONI, as revealed by similar lag correlations between DMI and ONI (Figure 10e).

(a) First EOF mode of monthly SSC anomaly

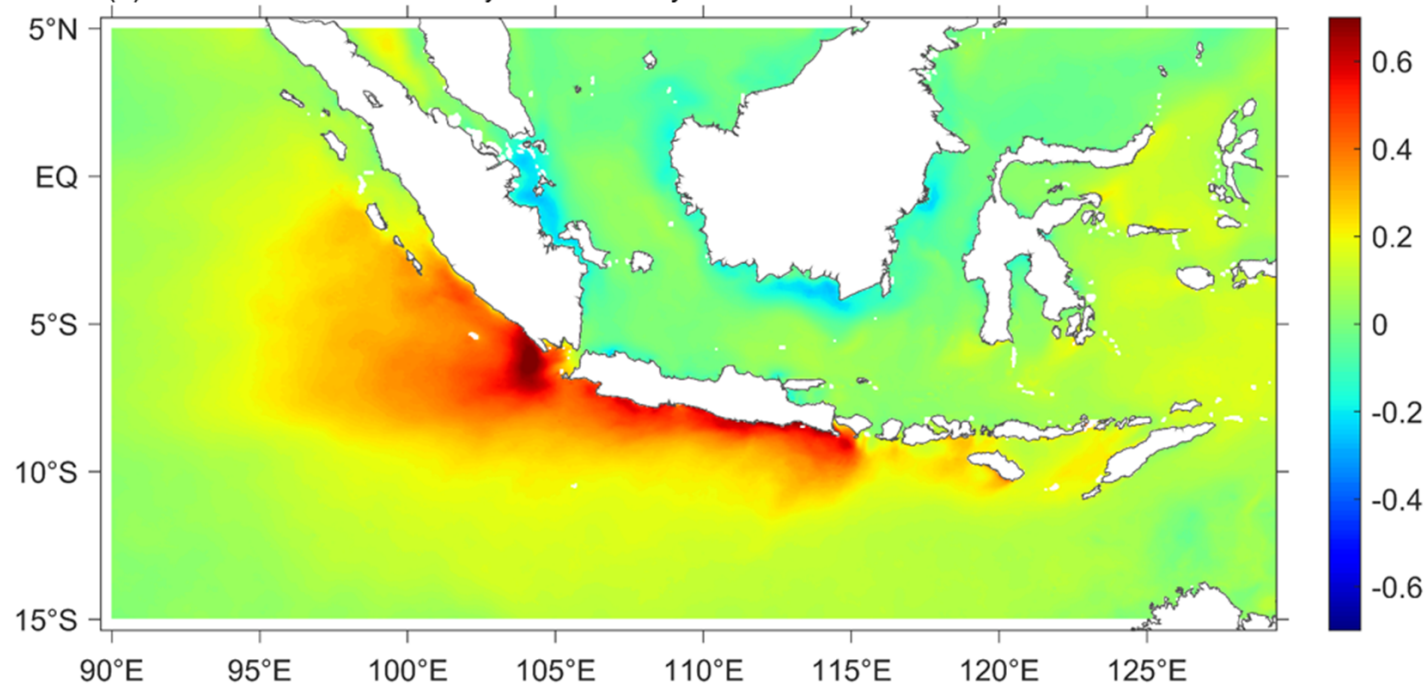

(b) 3-month running mean time series
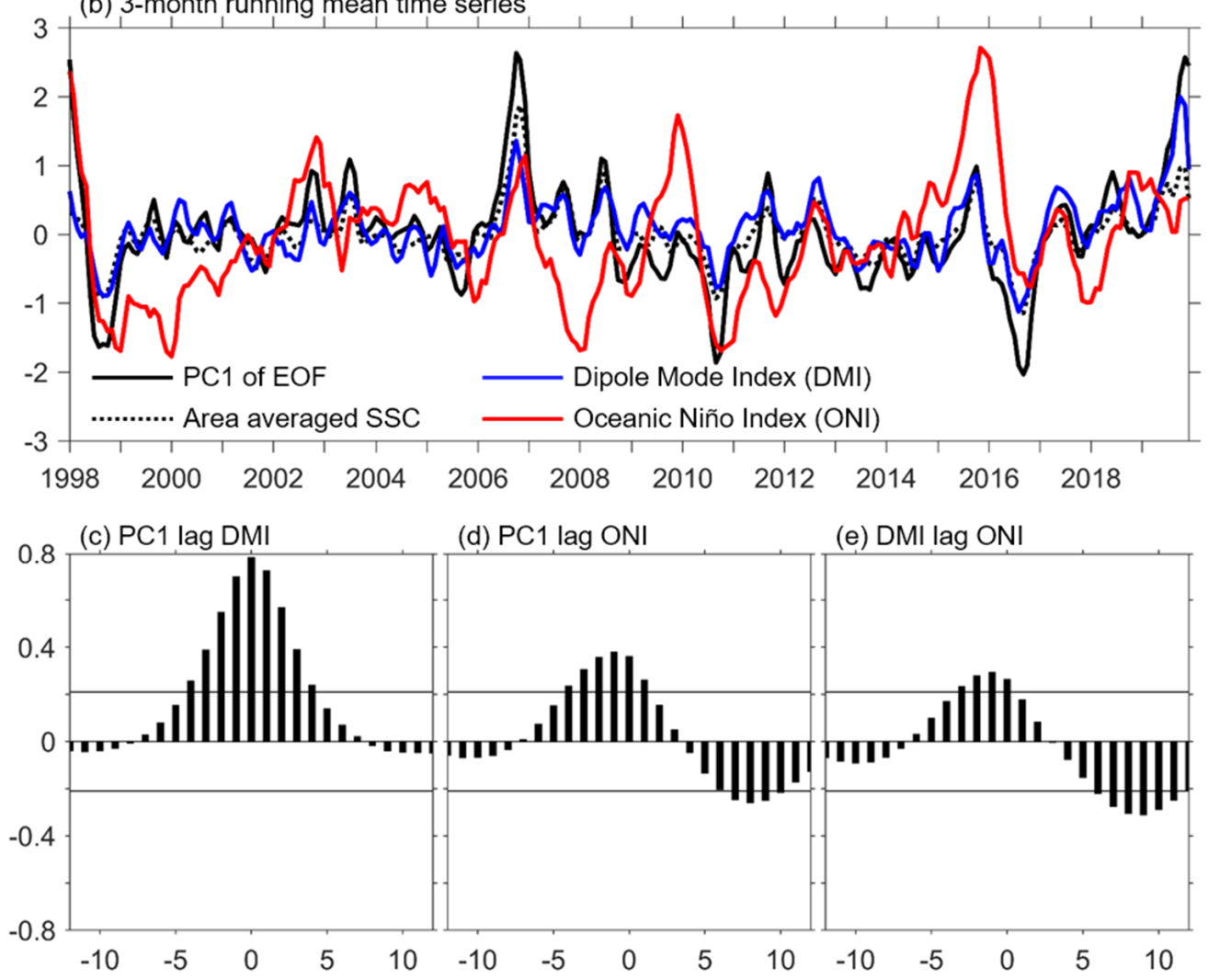

Figure 10. (a) The first EOF mode of the monthly SSC anomalies; (b) Three-month running time coefficient of the first EOF mode (PC1), area averaged SSC anomalies along the south coast of Sumatra-Java Islands, and DMI and ONI indices; and lag correlations between (c) PC1 and DMI; (d) PC1 and ONI; and (e) DMI and ONI. The positive/negative days on the x-axis in (c-e) indicate PC1 lagging/leading DMI, PC1 lagging/leading ONI, and DMI lagging/leading ONI, respectively. 
We define the positive and negative IOD events as those above $0.5^{\circ} \mathrm{C}$ and below $-0.5^{\circ} \mathrm{C}$, respectively. The typical positive IOD years are identified as 2003, 2006, 2008, 2011, 2012, 2015, 2017, and 2019, while the negative IOD years are 1998, 2001, 2010, 2013, and 2016, and normal years are 1999, 2004, 2005, 2009, and 2014. The composite SSC and SSH during the positive and negative IOD events are generally out of phase with each other (Figure 11a,b). During the positive IOD events, there are cold SST anomalies and anomalous upwellings along the south coasts of Sumatra and Java. This favors nutrient-rich waters below the thermocline being vertically entrained into the mixed layer, resulting in positive SSC anomalies. On the contrary, the entrainment tends to be depressed because of anomalous downwelling that favor a deepened thermocline, thereby resulting in negative SSC anomalies during negative IOD events. Both the SSH and SSC anomalies are small during the normal years.
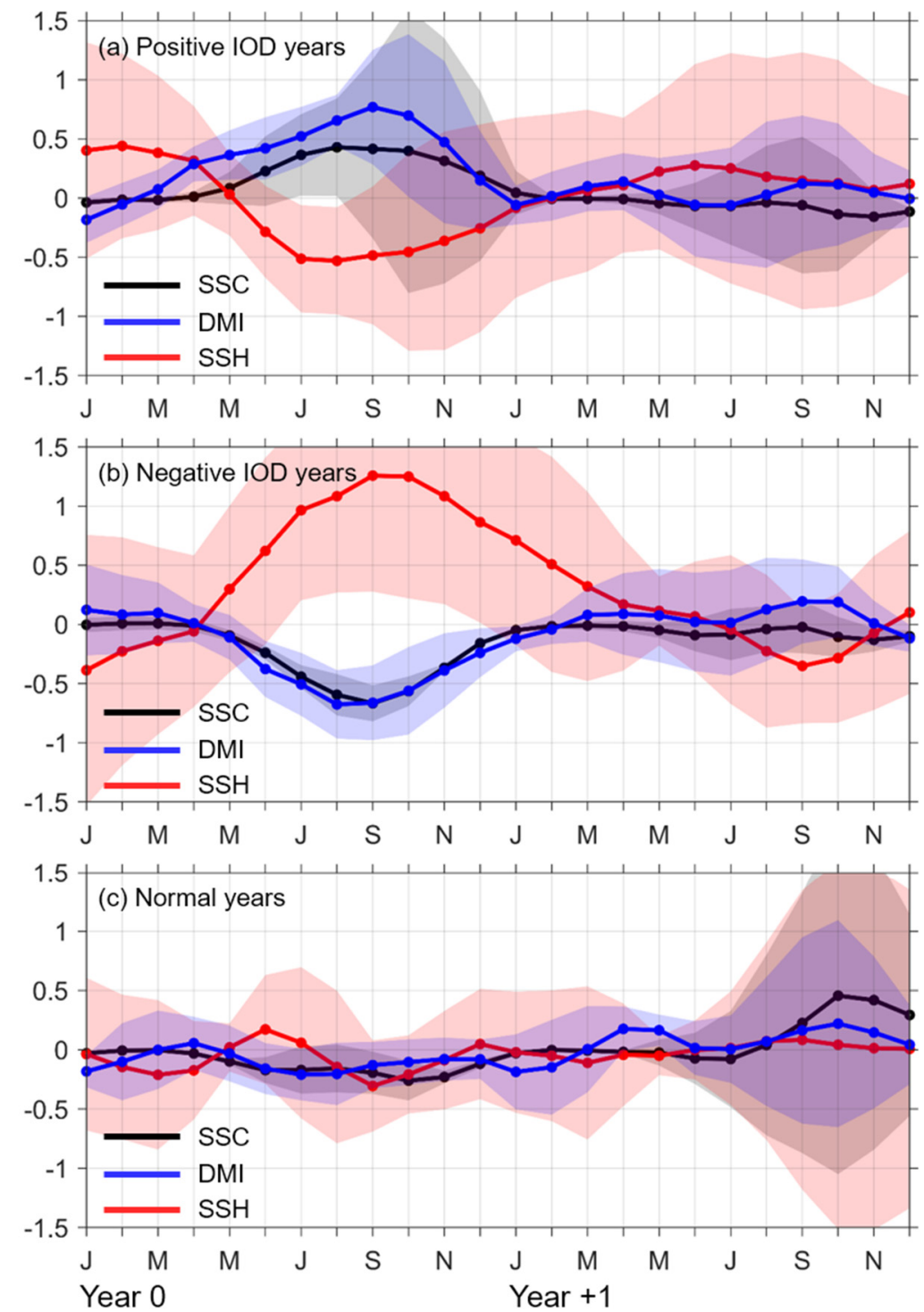

Figure 11. Composite SSC, DMI, and SSH during (a) positive IOD; (b) negative IOD; and (c) normal and following years. Year 0 and Year +1 refer to the IOD events and the following years, respectively. The unit of SSH is $10^{-1} \mathrm{~m}$. Light shadings in $(\mathbf{a}-\mathbf{c})$ indicate the standard deviation of the composite SSC (gray), DMI (blue), and SSH (red).

The long-term trend in SSC is not significant in the Indonesian seas or the southeastern tropical Indian Ocean, with values generally between $\pm 0.1 \mathrm{mg} / \mathrm{m}$ per decade (Figure 12a). 
The SSC trend might not be attributed to the SSH trends, since the SSH show positive trend over the entire study region, except in the vicinity of Australia (Figure 12b). Rather, the trends in Ekman pumping have shown positive values along the south coast of the Sumatra and Java Islands and, thus, may contribute to the enhancement of the vertical transport in the upper layer (Figure 12c). As a result, the SSC would increase accordingly.

(a) SSC trend $\left(\mathrm{mg} / \mathrm{m}^{3} /\right.$ decade $)$

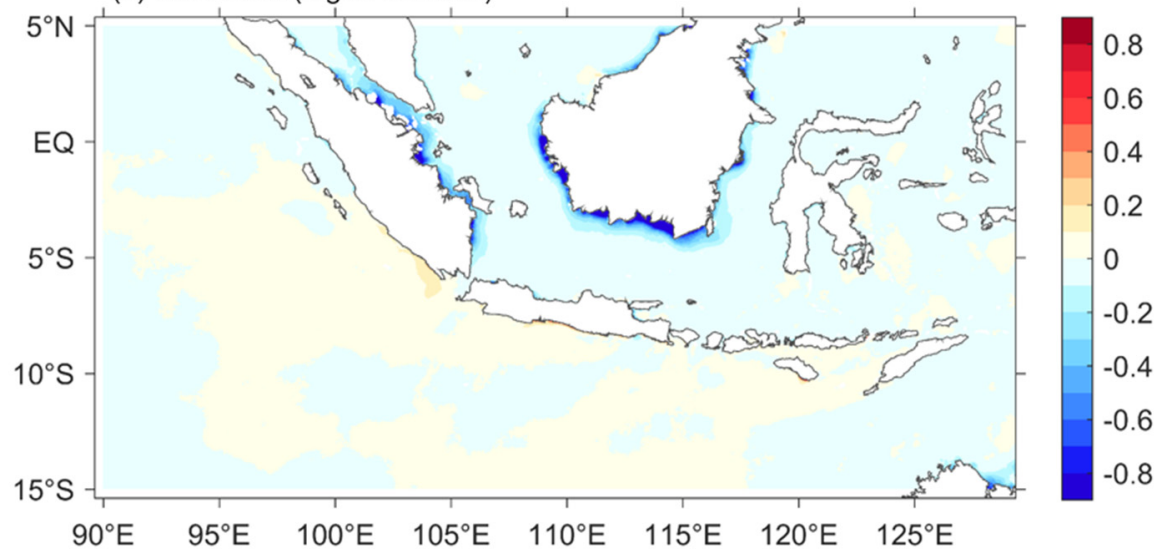

(b) $\mathrm{SSH}$ trend ( $\mathrm{m} / \mathrm{decade})$

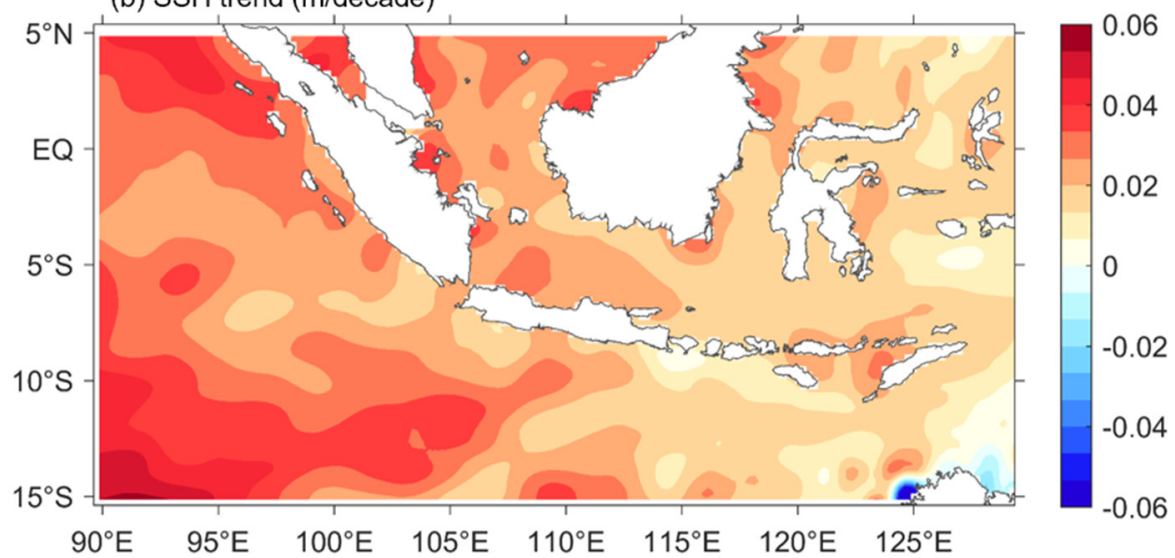

(c) Ekman pumping trend $\left(10^{-5} \mathrm{~m} / \mathrm{s} /\right.$ decade)

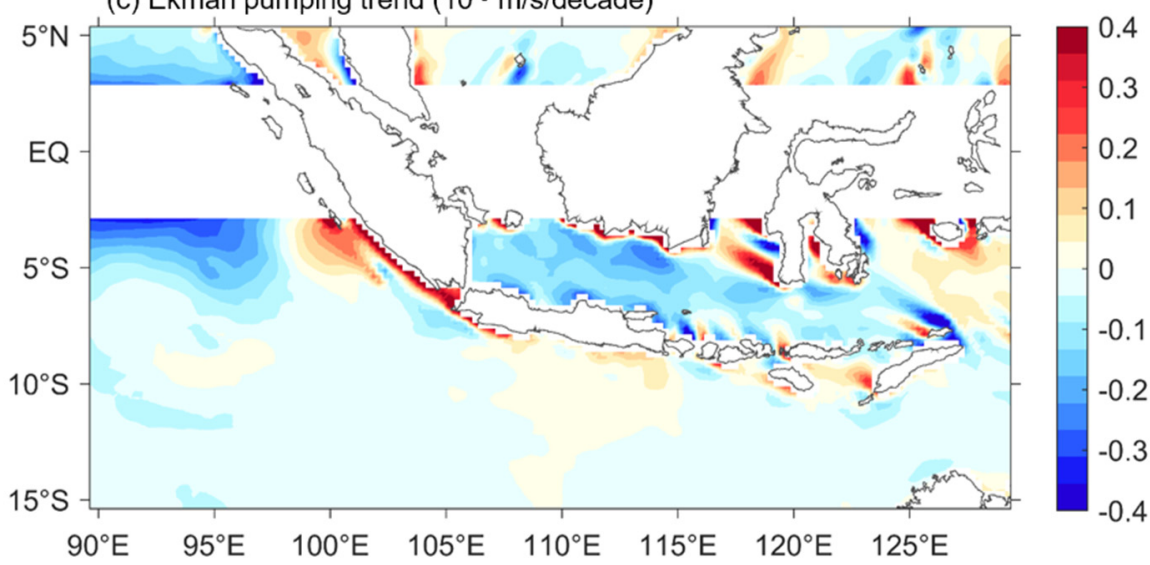

Figure 12. Long-term trend during the period of 1998 to 2019 in (a) SSC; (b) SSH; and (c) Ekman pumping.

\section{Discussion}

The region along the south coast of the Sumatra and Java Islands is known as a notable upwelling region, thereby feeding fishery within the area. The high productivity can be detected by remote sensing SSC. Previous investigations have revealed that the seasonal SSC is a consequence of the monsoon-driven coastal upwelling, with higher and lower values 
occurring during the upwelling and non-upwelling seasons, respectively [51]. Case studies have also suggested that ENSO and IOD events impact the SSC along the Sumatra-Java south coast [12,14,33-38]. Our analyses based on a recently released high resolution SSC remote sensing product corroborate that monsoon-driven upwelling dominates seasonal SSC along the south coast of the Sumatra and Java Islands. Furthermore, we found that the seasonal SSC in the Indonesian seas side of the Sumatra-Java Islands is out of phase with that in the Indian Ocean side [14]. This is attributed to the rainy and dry seasons co-occurring with the non-upwelling and upwelling seasons, respectively, which are both driven by monsoon. Heavy rainfall induces larger river discharges from the Sumatra and Kalimantan Islands, thereby providing nutrients for the SSC bloom surrounding the Sumatra and Kalimantan Islands. Local Ekman pumping also contributes to the SSC seasonal variability, whereas rainfall input to the ocean plays little role.

The equatorial Indian Ocean is known as the source of the MJO [57,58], which forces intraseasonal Kelvin waves to propagate eastward along the equator and south coast of the Sumatra-Java Islands $[16,40,59]$. Our previous investigation showed that the propagation of intraseasonal Kelvin waves could induce an SSH gradient along the Sunda Strait, favoring strong intraseasonal along-strait flow to transport SSC from the Java Sea to the Indian Ocean during the monsoon transition season [42]. The results of the present study showed that such processes do not work in the Lombok Strait, since there is rarely river discharge to supply high SSC in the north of the Lombok Strait. Nevertheless, lag correlation and composite analyses suggest that propagation of the coastal trapped intraseasonal Kelvin waves is responsible for the intraseasonal SSC anomalies along the south coast of Sumatra and Java. In addition, the intraseasonal SSC anomalies south of the Sunda and Lombok straits are attributed to the active mesoscale eddies in the southeastern tropical Indian Ocean, which is reminiscent the phenomenon that high SSC co-occurred with the Sri Lanka dome [5-7].

The interannual SSC anomalies are strongly associated with IOD-induced anomalous upwellings along the south coast of the Sumatra and Java Islands. Although it is also statistically correlated with ONI by a time lag of by 6-11 months, the underlying mechanism should be attributed to the link between the IOD and ENSO. It should be noted that there was only a weak increasing trend along the south coast of the Sumatra and Java Islands. The SSH shows increasing trend, suggesting deepening of the thermocline, favoring to inhibit the nutrient-rich water entrained to the surface and subsequently resulting in decrease in SSC along the south coast of the Sumatra and Java Islands. On the contrary, there is enhanced local Ekman pumping, suggesting a more active upwelling process to bring more nutrient-rich water from the deeper layer to the mixed layer. Therefore, the increasing trend in SSC may be explained mainly by the enhanced local Ekman pumping.

\section{Conclusions}

In this study, we analyze the seasonal, intraseasonal, and interannual variations and long-term trends in the SSC along the south coast of the Sumatra and Java Islands based on satellite remote sensing products of SSC, SST, SSH, SSW, and precipitation, as well as re-analysis of river discharge. The conclusions are summarized as follows:

(1) The SSC is subject to strong seasonal variability because of monsoon-driven upwellings and rainfall-induced river discharges in the Indian Ocean and Indonesian seas side of the Sumatra and Java Islands. The area averaged climatology SSCs are approximately $0.75 \mathrm{mg} / \mathrm{m}^{3}$ in the Indian Ocean side during the upwelling season, while this decreases to $0.25 \mathrm{mg} / \mathrm{m}^{3}$ during the non-upwelling season. The area averaged climatology SSCs in the Indonesian seas side are 0.79 and $1.01 \mathrm{mg} / \mathrm{m}^{3}$ during the upwelling (dry) and non-upwelling (rainy) seasons, respectively.

(2) The coastally trapped Kelvin waves and mesoscale eddies are responsible for the intraseasonal SSC anomalies in regions along the south coast of Java and off the Sunda and Lombok Straits, respectively. 
(3) The interannual SSC anomalies along the south coast of the Sumatra and Java Islands are closely associated with IOD-induced anomalous upwellings therein. Meanwhile, the correlations between the interannual SSC anomalies and ONI show significant negative correlations with the former lagging by 6-11 months. However, the significant lag correlations are because the IOD events often lag ENSO by 6-11 months.

(4) The SSC s do not show a significant trend in the southeastern tropical Indian Ocean from 1998 to 2019, with values generally being between $\pm 0.1 \mathrm{mg} / \mathrm{m}$ per decade. The trend in local Ekman transport, rather than SSH, explains the weak increase in SSC along the south coast of the Sumatra and Java Islands.

Author Contributions: Conceptualization, T.X. and Z.W.; Formal analysis, T.X. and Z.W.; Investigation, T.X. and S.L.; Methodology, T.X.; Project administration, T.X.; Resources, T.X.; Software, R.D.S.; Supervision, Z.W.; Validation, Z.W., S.L. and R.D.S.; Visualization, T.X.; Writing-original draft, T.X.; Writing-review \& editing, Z.W., S.L., R.D.S., N.R., C.Y., A.S., A.K., T.A. and M.T. All authors have read and agreed to the published version of the manuscript.

Funding: This research was funded by the National Key Research and Development Program of China (Grant No. 2017YFC1404201), the National Natural Science Foundation of China (Grant Nos. 42076023 and 42076024), the MNR Program on Global Change and Air-Sea interactions (GASI-04WLHY-03), and the China-Indonesia Maritime Cooperation Fund: Construction of ICCOC and Joint Observation Stations. R.D.S. is supported by NASA grants 80NSSC18K0777 and NNX17AE79A through the University of Maryland, College Park.

Institutional Review Board Statement: Not applicable.

Informed Consent Statement: Not applicable.

Data Availability Statement: The data presented in this study are openly and freely available. SSC data are available at https:/ / resources.marine.copernicus.eu/?option=com_csw\&view=detail s\&product_id=OCEANCOLOUR_GLO_CHL_L4_REP_OBSERVATIONS_009_082 (accessed on 30 November 2020), WOD2018 data are available at https: / www.ncei.noaa.gov / products / world-o cean-database (accessed on 30 November 2020), GHRSST SST data are available at https:/ / poda ac.jpl.nasa.gov / dataset/UKMO-L4HRfnd-GLOB-OSTIA (accessed on 30 November 2020), AVISO SSH and sea surface geostrophic currents data are available at http:/ / www.aviso.altimetry.fr/duacs (accessed on 30 November 2020), CCMP wind data are available at http:/ / www.remss.com/me asurements/ccmp (accessed on 30 November 2020), TRMM precipitation data are avaiable at https:/ / disc.gsfc.nasa.gov/datasets/TRMM_3B42_Daily_7/summary (accessed on 30 November 2020). GloFAS-ERA5 river discharge data are available at https:/ / cds.climate.copernicus.eu/cdsapp \#! / dataset/cems-glofas-historical?tab=overview (accessed on 30 November 2020).

Conflicts of Interest: The authors declare no conflict of interest.

\section{References}

1. Martinez, E.; Brini, A.; Gorgues, T.; Drumetz, L.; Roussillon, J.; Tandeo, P.; Maze, G.; Fablet, R. Neural Network Approaches to Reconstruct Phytoplankton Time-Series in the Global Ocean. Remote Sens. 2020, 12, 4156. [CrossRef]

2. Carr, M.; Friedrichs, M.; Schmeltz, M.; Noguchi, A.; Antoine, D.; Arrigo, K.; Asanuma, I.; Aumont, O.; Barber, R.; Behrenfeld, M. A comparison of global estimates of marine primary production from ocean color. Deep Sea Res. Part II 2006, 53, 741-770. [CrossRef]

3. Taboada, F.G.; Barton, A.D.; Stock, C.A.; Dunne, J.; John, J.G. Seasonal to interannual predictability of oceanic net primary production inferred from satellite observations. Prog. Oceanogr. 2019, 170, 28-39. [CrossRef]

4. Zhao, D.; Xu, Y.; Zhang, X.; Huang, C. Global chlorophyll distribution induced by mesoscale eddies. Remote Sens Environ. 2021, 254, 112245. [CrossRef]

5. Lozovatsky, I.; Wijesekera, H.; Jarosz, E.; Lilover, M.-J.; Pirro, A.; Silver, Z.; Centurioni, L.; Fernando, H.J.S. A snapshot of internal waves and hydrodynamic instabilities in the southern Bay of Bengal. J. Geophys. Res. Oceans 2016, 121, 5898-5915. [CrossRef]

6. Pirro, A.; Fernando, H.J.S.; Wijesekera, H.W.; Jensen, T.G.; Centurioni, L.R.; Jinadasa, S.U.P. Eddies and currents in the Bay of Bengal during summer monsoons. Deep Sea Res. II 2020, 172, 104728. [CrossRef]

7. Thushara, V.; Vinayachandran, P.N.M.; Matthews, A.J.; Webber, B.G.M.; Queste, B.Y. Vertical distribution of chlorophyll in dynamically distinct regions of the southern Bay of Bengal. Biogeosciences 2019, 16, 1447-1468. [CrossRef]

8. Gregg, W.W.; Rousseaux, C.S.; Franz, B.A. Global trends in ocean phytoplankton: A new assessment using revised ocean colour data. Remote Sens. Lett. 2017, 8, 1102-1111. [CrossRef] [PubMed] 
9. Syamsuddin, M.; Kaneko, A. Ocean variability along the southern coast of Java and Lesser Sunda Islands. J. Oceanogr. 2013, 69, 557-570. [CrossRef]

10. Syamsuddin, M.; Saitoh, S.I.; Hirawake, T.; Syamsudin, F.; Zainuddin, M. Interannual variation of bigeye tuna (Thunnus obesus) hotspots in the eastern Indian Ocean off Java. Int. J. Remote Sens. 2016, 37, 2087-2100. [CrossRef]

11. Lahlali, H.; Wirasatriya, A.; Gensac, E.; Helmi, M.; Kunarso; Kismawardhani, R.A. Environmental Aspects of Tuna Catches in the Indian Ocean, Southern Coast of Java, Based on Satellite Measurements. In Proceedings of the 2018 th International Symposium on Geoinformatics (ISyG), Malang, Indonesia, 10 November 2018.

12. Wirasatriya, A.; Setiawan, J.D.; Sugianto, D.N.; Rosyadi, I.A.; Haryadi, H.; Winarso, G.; Setiawan, R.Y.; Susanto, R.D. Ekman dynamics variability along the southern coast of Java revealed by satellite data. Int. J. Remote Sens. 2020, 41, 8475-8496. [CrossRef]

13. Hendiarti, N.; Siegel, H.; Ohde, T. Investigation of different coastal processes in Indonesian waters using SeaWiFS data. Deep-Sea Res. Part II-Top. Stud. Oceanogr. 2004, 51, 85-97.

14. Susanto, R.D.; Moore, T.S., II; Marra, J. Ocean color variability in the Indonesian Seas during the SeaWiFS era. Geochem. Geophy. Geosy. 2006, 7, Q05021. [CrossRef]

15. Chen, G.; Han, W.; Li, Y.; Wang, D. Interannual Variability of Equatorial Eastern Indian Ocean Upwelling: Local versus Remote Forcing. J. Phys. Oceanogr. 2016, 46, 789-807. [CrossRef]

16. Schiller, A.; Wijffels, S.E.; Sprintall, J.; Molcard, R.; Oke, P.R. Pathways of intraseasonal variability in the Indonesian Throughflow region. Dyn. Atmos. Oceans 2010, 50, 174-200. [CrossRef]

17. Iskandar, I.; Masumoto, Y.; Mizuno, K.; Sasaki, H.; Affandi, A.K.; Setiabudidaya, D.; Syamsuddin, F. Coherent intraseasonal oceanic variations in the eastern equatorial Indian Ocean and in the Lombok and Ombai Straits from observations and a high-resolution OGCM. J. Geophys. Res. Oceans 2014, 119, 615-630. [CrossRef]

18. Chen, G.; Han, W.; Li, Y.; Wang, D.; Shinoda, T. Intraseasonal variability of upwelling in the equatorial Eastern Indian Ocean. J. Geophys. Res. Oceans 2015, 120, 7598-7615. [CrossRef]

19. Horii, T.; Ueki, I.; Ando, K. Coastal upwelling events along the southern coast of Java during the 2008 positive Indian Ocean Dipole. J. Oceanogr. 2018, 74, 499-508. [CrossRef]

20. Susanto, R.D.; Gordon, A.L.; Zheng, Q.N. Upwelling along the coasts of Java and Sumatra sand its relation to ENSO. Geophys. Res. Lett. 2001, 28, 1599-1602. [CrossRef]

21. Wei, X.; Liao, X.; Zhan, H.; Liu, H. Estimates of potential new production in the Java-Sumatra upwelling system. Chin. J. Oceanol. Limnol. 2012, 30, 1063-1067. [CrossRef]

22. Lumban-Gaol, J.; Leben, R.R.; Vignudelli, S.; Mahapatra, K.; Okada, Y.; Nababan, B.; Mei-Ling, M.; Amri, K.; Arhatin, R.E.; Syahdan, M. Variability of satellite-derived sea surface height anomaly, and its relationship with Bigeye tuna (Thunnus obesus) catch in the Eastern Indian Ocean. Eur. J. Remote Sens. 2015, 48, 465-477. [CrossRef]

23. Hood, R.R.; Beckley, L.E.; Wiggert, J.D. Biogeochemical and ecological impacts of boundary currents in the Indian Ocean. Prog. Oceanogr. 2017, 156, 290-325. [CrossRef]

24. Romero, O.E.; Rixen, T.; Herunadi, B. Effects of hydrographic and climatic forcing on diatom production and export in the tropical southeastern Indian Ocean. Mar. Ecol. Prog. Ser. 2009, 384, 69-82. [CrossRef]

25. Milliman, J.D.; Farnsworth, K.L. River Discharge to the Coastal Ocean: A Global Synthesis; Cambridge University Press: New York, NY, USA, 2011; pp. 316-323.

26. Koropitan, A.F.; Ikeda, M. Influences of physical processes and anthropogenic influx on biogeochemical cycle in the Java Sea: Numerical model experiment. Procedia Environ. Sci. 2016, 33, 532-552. [CrossRef]

27. Sachoemar, S.I.; Yanagi, T.; Aliah, R.S. Variability of sea surface chlorophyll-a, temperature and fish catch within Indonesian region rivealed by satellite data. Mar. Res. Indonesia 2012, 37, 75-87. [CrossRef]

28. Syamsuddin, M.; Sunarto; Yuliadi, L. Seasonal Variations of Oceanographic Variables and Eastern Little Tuna (Euthynnus affinis) Catches in the North Indramayu Waters Java Sea. In Proceedings of the 3rd International Conference on Tropical and Coastal Region Eco Development 2017, Yogyakarta, Indonesia, 2-4 October 2017; Riyadi, M.A., Winarni, T.I., Wijayanti, D.P., Tsuchiya, M., Susanto, H., Jamari, G.H., Ambariyanto, Z.M., Faraz, S.M., Pals, G., Eds.; IOP Publishing: Philadelphia, PA, USA, 2018; Volume 116, p. 012073.

29. Behrenfeld, M.J.; Falkowski, P.G. Photosynthetic Rates Derived from Satellite-Based Chlorophyll Concentration. Limnol. Oceanogr. 1997, 42, 1-20. [CrossRef]

30. Campbell, J.; Antoine, D.; Armstrong, R.; Arrigo, K.; Balch, W.; Barber, R.; Behrenfeld, M.; Bidigare, R.; Bishop, J.; Carr, M.E. Comparison of algorithms for estimating ocean primary production from surface chlorophyll, temperature, and irradiance. Glob. Biogeochem. Cycl. 2002, 16, 1-15. [CrossRef]

31. Kong, F.; Dong, Q.; Xiang, K.; Yin, Z.; Li, Y.; Liu, J. Spatiotemporal Variability of Remote Sensing Ocean Net Primary Production and Major Forcing Factors in the Tropical Eastern Indian and Western Pacific Ocean. Remote Sens. 2019, 11, 391. [CrossRef]

32. Osawa, T.; Julimantoro, S. Study of Fishery Ground around Indonesia Archipelago Using Remote Sensing Data. In Adaptation and Mitigation Strategies for Climate Change; Sumi, A., Fukushi, K., Hiramatsu, A., Eds.; Springer: Tokyo, Japan, 2010; Chapter 4; pp. 57-69.

33. Siswanto, E.; Horii, T.; Iskandar, I.; Gaol, J.L.; Setiawan, R.Y.; Susanto, R.D. Impacts of climate changes on the phytoplankton biomass of the Indonesian Maritime Continent. J. Mar. Syst. 2020, 212, 103451. [CrossRef] 
34. Susanto, R.D.; Marra, J. Effect of the 1997/98 El Nino on Chlorophyll-a Variability along the Southern Coasts of Java and Sumatra. Oceanography 2005, 4, 124-127. [CrossRef]

35. Setiawan, R.Y.; Setyobudi, E.; Wirasatriya, A.; Muttaqin, A.S.; Maslukah, L. The Influence of Seasonal and Interannual Variability on Surface Chlorophyll-a Off the Western Lesser Sunda Islands. IEEE J. Stars 2019, 12, 4191-4197. [CrossRef]

36. Iskandar, I.; Rao, S.A.; Tozuka, T. Chlorophyll-a bloom along the southern coasts of Java and Sumatra during 2006. Int. J. Remote Sens. 2009, 30, 663-671. [CrossRef]

37. Iskandar, I.; Sasaki, H.; Sasai, Y.; Masumoto, Y.; Mizuno, K. A numerical investigation of eddy-induced chlorophyll bloom in the southeastern tropical Indian Ocean during Indian Ocean Dipole-2006. Ocean Dyn. 2010, 60, 731-742. [CrossRef]

38. Sari, Q.W.; Utari, P.A.; Setiabudidaya, D.; Yustian, I.; Siswanto, E.; Iskandar, I. Surface chlorophyll-a variations in the Southeastern Tropical Indian Ocean during various types of the positive Indian Ocean Dipole events. Int. J. Remote Sens. 2020, 41, 171-184. [CrossRef]

39. Qiu, B.; Mao, M.; Kashino, Y. Intraseasonal variability in the Indo-Pacific throughflow and the regions surrounding the Indonesian Seas. J. Phys. Oceanogr. 1999, 29, 1599-1618. [CrossRef]

40. Iskandar, I.; Mardiansyah, W.; Masumoto, Y.; Yamagata, T. Intraseasonal Kelvin Waves along the Southern Coast of Sumatra and Java. J. Geophys. Res. 2005, 119, C04013. [CrossRef]

41. Li, S.; Wei, Z.; Susanto, R.D.; Zhu, Y.; Setiawan, A.; Xu, T.; Fan, B.; Agustiadi, T.; Trenggono, M.; Fang, G. Observations of intraseasonal variability in the Sunda Strait throughflow. J. Oceanogr. 2018, 74, 541-547. [CrossRef]

42. Xu, T.; Li, S.; Hamzah, F.; Setiawan, A.; Susanto, R.D.; Cao, G.; Wei, Z. Intraseasonal flow and its impact on the chlorophyll-a concentration in the Sunda Strait and its vicinity. Deep Sea Res. Part I Oceanogr. Res. Pap. 2018, 136, 84-90. [CrossRef]

43. Drushka, K.; Sprintall, J.; Gille, S.T.; Brodjonegoro, I. Vertical Structure of Kelvin Waves in the Indonesian Throughflow Exit Passages. J. Phys. Oceanogr. 2010, 40, 1965-1987. [CrossRef]

44. Garnesson, P.; Mangin, A.; Bretagnon, M. Quality Information Document: Ocean Colour Production Centre Satellite Observation Copernicus-GlobColour Pruducts. Available online: https:/ / resources.marine.copernicus.eu/documents/QUID/CMEMS-OC-Q UID-009-030-032-033-037-081-082-083-085-086-098.pdf (accessed on 24 June 2020).

45. Boyer, T.P.; Baranova, O.K.; Coleman, C.; Garcia, H.E.; Grodsky, A.; Locarnini, R.A.; Mishonov, A.V.; Paver, C.R.; Reagan, J.R.; Seidov, D.; et al. World Ocean Database 2018; Mishonov, A.V., Ed.; NOAA Atlas NESDIS 87; 2018. Available online: https: //www.ncei.noaa.gov/sites/default/files/2020-04/wod_intro_0.pdf (accessed on 30 November 2020).

46. Donlon, C.J.; Casey, K.S.; Robinson, I.S.; Gentemann, C.L.; Reynolds, R.W.; Barton, I.; Arino, O.; Stark, J.; Rayner, N.; Leborgne, P.; et al. The Godae High-Resolution Sea Surface Temperature Pilot Project. Oceanography 2009, 22, 34-45. [CrossRef]

47. Donlon, C.; Robinson, I.; Casey, K.S.; Vazquez-Cuervo, J.; Armstrong, E.; Arino, O.; Gentemann, C.; May, D.; LeBorgne, P.; Piolle, J.; et al. The global ocean data assimilation experiment high-resolution sea surface temperature pilot project. $B A m$. Meteorol. Soc. 2007, 88, 1197-1213. [CrossRef]

48. Ducet, N.; Le Traon, P.Y.; Reverdin, G. Global high-resolution mapping of ocean circulation from TOPEX/Poseidon and ERS-1 and-2. J. Geophys. Res. Oceans 2000, 105, 19477-19498. [CrossRef]

49. Atlas, R.; Hoffman, R.N.; Ardizzone, J.; Leidner, S.M.; Jusem, J.C.; Smith, D.K.; Gombos, D. A Cross-Calibrated Multiplatform Ocean Surface Wind Velocity Product for Meteorological and Oceanographic Applications. B Am. Meteorol. Soc. 2011, 92, 157-174. [CrossRef]

50. Huffman, G.J.; Bolvin, D.T.; Nelkin, E.J.; Adler, R.F. TRMM (TMPA) Precipitation L3 1 Day 0.25 Degree $\times 0.25$ Degree V7, Edited by Andrey Savtchenko, Goddard Earth Sciences Data and Information Services Center (GES DISC). 2016. Available online: https:/ / cmr.earthdata.nasa.gov/search/concepts/C1282032631-GES_DISC.html (accessed on 30 November 2020).

51. Harrigan, S.; Zsoter, E.; Alfieri, L.; Prudhomme, C.; Salamon, P.; Wetterhall, F.; Barnard, C.; Cloke, H.; Pappenberger, F. GloFAS-ERA5 operational global river discharge reanalysis 1979-present. Earth Syst. Sci. Data 2020, 12, 2043-2060. [CrossRef]

52. Greene, C.A.; Thirumalai, K.; Kearney, K.A.; Delgado, J.M.; Schwanghart, W.; Wolfenbarger, N.S.; Thyng, K.M.; Gwyther, D.E.; Gardner, A.S.; Blankenship, D.D. The Climate Data Toolbox for MATLAB. Geochem. Geophys. Geosystems 2019. [CrossRef]

53. Zhang, Z.; Moore, J.C. Empirical Orthogonal Functions. In Mathematical and Physical Fundamentals of Climate Change; Zhang, Z., Moore, J.C., Eds.; Elsevier: Amsterdam, The Netherlands, 2015; pp. 161-197.

54. Wang, Y.; Ma, W.; Zhou, F.; Chai, F. Frontal variability and its impact on chlorophyll in the Arabian sea. J. Mar. Syst. 2021, 218, 103545. [CrossRef]

55. Park, J.; Oh, I.-S.; Kim, H.-C.; Yoo, S. Variability of SeaWiFs chlorophyll-a in the southwest Atlantic sector of the Southern Ocean: Strong topographic effects and weak seasonality. Deep Sea Research I 2010, 57, 604-620. [CrossRef]

56. Saji, N.H.; Goswami, B.N.; Vinayachandran, P.N.; Yamagata, T. A dipole mode in the tropical Indian Ocean. Nature 1999, 401, 360-363. [CrossRef]

57. Madden, R.A.; Julian, P.R. Observations of the 40-50-day tropical oscillation-A review. Mon. Weather Rev. 1994, 122, 814-837. [CrossRef]

58. Zhou, L.; Murtugudde, R. Oceanic Impacts on MJOs Detouring near the Maritime Continent. J. Clim. 2020, 33, 2371-2388. [CrossRef]

59. Xu, T.F.; Wei, Z.X.; Cao, G.J.; Li, S.J. Pathways of intraseasonal Kelvin waves in the Indonesian Throughflow regions derived from satellite altimeter observation. Atmos. Ocean. Sci. Lett. 2016, 9, 375-380. [CrossRef]

60. Yang, G.; Zhao, X.; Li, Y.; Liu, L.; Yu, W. Chlorophyll variability induced by mesoscale eddies in the southeastern tropical indian ocean. J. Mar. Syst. 2019, 199, 103209. [CrossRef] 